\title{
HISTORICIZING THE ENCOUNTER BETWEEN STATE, CORPORATE, AND INDIGENOUS AUTHORITIES ON GITXSAN LANDS
}

\author{
Tyler McCreary*
}

This essay charts the shifting assemblage of the conduct of state, corporate, and Indigenous authority through four historical moments: mercantilism, settler colonialism, Indigenous resurgence, and corporate reconciliation. With reference to Gitxsan territories, it makes a series of interrelated arguments. The development of colonial territorial claims and regimes of governance overlapped pre-existent and ongoing Indigenous territorial relationships. The historical division between the political and economic domain reshaped the relationship between state and corporate authorities, the state deferring to corporate actors to manage relations in the economic domain. The conduct of state and corporate authorities has constrained and modified the exercise of Indigenous jurisdiction. Nevertheless, Indigenous resurgence has opened space for renegotiating the colonial legal order, including relations between extractive resource companies and Indigenous authorities. Emergent corporate practices of contracting with Indigenous authorities over development, however, reflect a reconfiguration rather than rupture of the settler colonial legal order. Corporate-Indigenous agreements rely upon colonial modes of organizing lawful political and economic conduct, and continue to block more radical and anti-colonial expressions of Indigenous jurisdiction. To expand possibilities for articulating forms of Indigenous jurisdiction that refuse the categories of colonial political economy, it is necessary to problematize the relationship between colonial state and corporate authority.

L'auteur de cet essai décrit l'évolution imbriquée de la conduite des instances de l'État, du monde des affaires et des peuples autochtones à travers quatre périodes de référence: le mercantilisme, le colonialisme de peuplement, la résurgence autochtone et la réconciliation avec le monde des affaires. En évoquant les territoires des Gitxsan, l'auteur présente plusieurs thèses liées entre elles. La constitution de revendications territoriales et de régimes de gouvernement coloniaux a empiété sur les relations préexistantes de longue date des peuples autochtones avec leur territoire. La division historique entre les domaines politique et économique a transformé les relations entre les

Assistant Professor, Department of Geography, Florida State University. Earlier versions of this paper were presented at the Third World Approaches to International Law Conference in Cairo, Egypt, and a subsequent workshop in Windsor, Canada. It has benefitted greatly from the feedback of conference and workshop organizers and participants. A number of colleagues and friends also took time to provide comments on earlier drafts, and the author particularly thanks Rebecca Hall, Claire Mumme, Melanie Sommerville, Jerome Turner, and the anonymous reviewers for their careful and constructive criticisms. The author also thanks Amar Bhatia, Usha Natarajan, John Reynolds, and Sujith Xavier for bringing me into the TWAIL conversation. For part of the time during which this research was conducted, the author was financially supported by a Social Science and Humanities Research Council of Canada postdoctoral fellowship in the Department of Geography at the University of British Columbia. 
instances de l'État et celles du monde des affaires, l'État s'en remettant aux acteurs du monde des affaires pour gérer les relations dans le domaine de l'économie. La conduite des instances de l'État et du monde des affaires a créé des contraintes pour l'exercice du pouvoir autochtone, qui s'en est trouvé modifié. Toutefois, la résurgence autochtone a ouvert une possibilité de renégocier l'ordre juridique colonial établi, notamment de changer les relations entre les entreprises extractives et les responsables autochtones. Par contre, les pratiques toutes récentes du monde des affaires, qui consistent à conclure des marchés avec les responsables autochtones concernant le développement, témoignent d'une reconfiguration plutôt que d'une rupture de l'ordre juridique colonial établi. Les ententes conclues entre les entreprises et les Autochtones reposent sur des modes coloniaux d'organisation de la conduite économique et politique légitime et continuent de faire obstacle aux modes d'expression plus radicaux et anticoloniaux du pouvoir autochtone. Pour élargir les possibilités d'expression des formes de pouvoir autochtones qui ne se prêtent pas aux catégories de l'économie politique coloniale, il est nécessaire de poser le problème des relations entre les instances de l'État colonial et celles du monde des affaires.

\section{INTRODUCTION}

In this paper, I explore the unfolding relationships between the conduct of state, corporate, and Indigenous authorities. Colonial regimes of state sovereignty have historically functioned to secure a legal foundation for corporate processes of accumulation on Indigenous lands. However, Indigenous territorial assertions have complicated the exercise of state and corporate power. To understand the morphing relationships between state, corporate, and Indigenous authorities, it is necessary to examine how different forms of jurisdiction meet. How is authority claimed, contested, and rendered effective? What modes of conduct shape how authority is exercised? When different forms of authority meet, what law governs that encounter?

I specifically situate my examinations in the Gitxsan encounter with colonialism. Located in the Northwest Interior of British Columbia, Canada, the Gitxsan people have maintained jurisdiction over their traditional territories since time immemorial. ${ }^{1}$ The Gitxsan people, like the majority of Indigenous peoples in British Columbia, have never ceded their territories. ${ }^{2}$ However, in the two centuries since contact with Europeans, state and corporate authorities have entered Gitxsan lands and sought to construct a frontier for extractive resource development. Gitxsan people have resisted these colonial programs of development, both historically and in the contemporary period. ${ }^{3}$ Gitxsan litigation and

1 Richard Daly, Our Box Was Full: An Ethnography for the Delgamuukw Plaintiffs (Vancouver: UBC Press, 2005); P Dawn Mills, For Future Generations: Reconciling Gitxsan and Canadian Law (Saskatoon: Purich Publishing, 2008).

2 Paul Tennant, Aboriginal Peoples and Politics: The Indian Land Question in British Columbia, $1849-1989$ (Vancouver: UBC Press, 1990); Cole Harris, Making Native Space: Colonialism, Resistance, and Reserves in British Columbia (Vancouver: UBC Press, 2002) [Harris, Making Space].

3 Neil J Sterritt, "Unflinching Resistance to an Implacable Invader" in Boyce Richardson, ed, Drumbeat: Anger and Renewal in Indian Country (Toronto: Sunhill Press, 1989) 267; Terry Glavin, A Death Feast in Dimlahamid (Vancouver: New Star Books, 1990); Robert Galois, “The History of the Upper Skeena Region, 1850 to 1927” (1993) 9:2 Native Stud 
direct action over the last three decades have challenged the territorial authority of the colonial state, generating legal uncertainties for resource development projects. ${ }^{4}$ Corporations have responded by developing new strategies of contracting with Indigenous communities to secure the legal grounds for development. ${ }^{5}$ Some scholars have represented these corporate-Indigenous negotiated agreements as an embodiment of Indigenous autonomy or sovereignty. ${ }^{6}$ In this paper, I argue a historical frame is required to understand contemporary transformations in how authority is claimed and exercised on Indigenous territories.

In order to place contemporary relations within a broader history, this essay tracks the relationships between state, corporate, and Indigenous forms of authority from mercantilism to the present. Doing so, I aim to disrupt narratives that herald corporate-Indigenous contracts as a decolonizing reversal of the colonial subjugation of Indigenous peoples. While relations between state, corporate, and Indigenous authorities have morphed, I argue that the exercise of Indigenous authority in corporate-Indigenous contracting relies upon and reproduces the legal structure undergirding the settler colonial political economy. Corporate-Indigenous contracts negotiated in the shadow of the settler state elide forms of Indigenous jurisdiction that do not accord with colonial modes of conducting lawful relations. This paper thus aims to historicize the forms of colonial jurisdiction that order the lawful conduct of resource development in British Columbia.

I argue that settler state authority to govern the land has been constituted through the cultivation of colonial regimes of territorial knowledge, the authorization of corporate actors to realize development aims, and the modification and displacement of Indigenous jurisdiction. The evolution of colonial forms of territorial knowledge played a key role in shaping political and economic logics, constituting the basis for both systems of governance and patterns of accumulation. Alongside colonial territorial visions, new models of conducting political and economic relations emerged in settler society. The development of settler colonialism coincided with a legal division of the political and economic domain, constraining state action and authorizing corporate bodies to pursue private profits within the economic sphere. The constitution of the Canadian settler colonial legal order has consistently delimited, modified, and displaced Indigenous forms of territorial jurisdiction.

While Indigenous legal resurgence has challenged the normative erasure of Indigenous territorial claims in British Columbia, the emergence of corporate techniques to legally secure development from Indigenous contestation do not fundamentally disrupt the legal order underlying the settler colonial political economy. Corporate-Indigenous contracts reflect colonial constructions of the land as a site for

Rev 113; Dara Culhane, The Pleasure of the Crown: Anthropology, Law and First Nations (Vancouver: Talonbooks, 1998) at 111-371; Mills, supra note 1 at 29-84.

4 Carole Blackburn, "Searching for Guarantees in the Midst of Uncertainty: Negotiating Aboriginal Rights and Title in British Columbia" (2005) 107:4 Am Anthropol 586.

5 Ciaran O'Faircheallaigh, "Community Development Agreements in the Mining Industry: An Emerging Global Phenomenon" (2013) 44:2 Community Dev 222 [O'Faircheallaigh, "Community Development"].

6 Jean Michel Montsion, "Disrupting Canadian Sovereignty? The 'First Nations \& China' Strategy Revisited" (2015) 58 Geoforum 114; Gabrielle Ann Slowey, Navigating Neoliberalism: Self-Determination and the Mikisew Cree First Nation (Vancouver: UBC Press, 2008) at 11-79 ; Ciaran O'Faircheallaigh, “Aboriginal-Mining Company Contractual Agreements in Australia and Canada: Implications for Political Autonomy and Community Development" (2010) 30:1/2 Can J Dev Stud 69 [O'Faircheallaigh, "Contractual Agreements"]. 
resource extraction, and neglect Indigenous modes of conducting lawful relations with the land as kin. Moreover, the methods of negotiating and upholding corporate-Indigenous agreements reflect colonial legal traditions, and often work in opposition to the modes of conducting lawful relations associated with Indigenous jurisdiction. In order to expand possibilities for the effective exercise of Indigenous jurisdiction, it remains necessary to problematize the normalization of colonial forms of jurisdiction within the relationships between state, corporate, and Indigenous authorities.

The paper is organized into seven sections. First, I outline my theoretical foundations in scholarship on jurisdiction. Second, I review how authority is constituted and exercised within Gitxsan legal orders. Third, I explore emergent relations between state, corporate, and Indigenous authorities in the mercantile period. Fourth, I examine the transformations that occurred as settler authorities sought to exploit the resources of the land, extend corporate authority, and displace Indigenous peoples. Fifth, I explore how contemporary Indigenous resurgence has resisted dispossession. Sixth, I address how recent corporateIndigenous agreements reconcile corporate development with the continued existence of Indigenous peoples. I conclude by reiterating the argument that the emergence of corporate-Indigenous agreements represents a revision rather than a rupture of the settler colonial political economic order.

\section{THEORIZING JURISDICTION}

The aim of this paper is to particularize colonial forms of jurisdiction, demonstrating how they displace other ways of organizing the conduct of lawful relations. In this section, I situate my work in relation to Third World Approaches to International Law [TWAIL] and the scholarship on jurisdiction. In developing this paper, I have been particularly inspired by jurisdictional analysis of the delimitations of Third World sovereignty. This led me to deeper engagements with the literature on jurisdiction, which helped me to conceptualize relationships between jurisdiction, authority, and modes of lawful conduct.

This paper began as an effort to extend the conversation between TWAIL and scholarship on Indigenous and tribal legalities. ${ }^{7}$ As Amar Bhatia highlights, there are important historic linkages and differences between Third World and Indigenous struggles against colonial domination and for selfdetermination. $^{8}$ The project of the Third World sought to articulate decolonial forms of state sovereignty. ${ }^{9}$ Submerged within imposed settler colonial state structures, Indigenous peoples asserted distinct non-state forms of jurisdiction and routes to self-determination. Mbutu Milando, First Secretary of the Tanzanian High Commission, reportedly told Secwepemc leader George Manuel, "When the Indian peoples come into their own, that will be the Fourth World." ${ }^{10}$ But if distinct relationships to state

7 Prabhakar Singh, "Indian International Law: From a Colonized Apologist to a Subaltern Protagonist" (2010) 23:01 Leiden J Int Law 79; Amar Bhatia, "The South of the North: Building on Critical Approaches to International Law with Lessons from the Fourth World" (2012) 14 Or Rev Intl Law 131.

8 Bhatia, supra note 7.

9 For a history of the Third World movement, see Vijay Prashad, The Darker Nations: A People's History of the Third World (New York: The New Press, 2007).

10 George Manuel \& Michael Posluns, The Fourth World: An Indian Reality (Don Mills: Collier-Macmillan Canada, 1974) at 5. Notably, Tanzanian government officials, under the leadership of Julius Nyerere, were key participants in articulating the project of the Third World. 
power differentiate Third World and Fourth World approaches, both movements express a desire for territorial jurisdiction.

Recent TWAIL scholarship directed my inquiries towards a deeper engagement with questions of jurisdiction. Employing the lens of jurisdiction, Shaun McVeigh and Sundhya Pahuja examine the delimitation of Third World efforts to enact sovereignty over natural resources within the international economic order. ${ }^{11}$ In the wake of decolonization, Third World nations had sought to use their sovereign authority to nationalize resources that had been unjustly granted as corporate concessions during the colonial period. ${ }^{12}$ However, Third World efforts to effect sovereignty over natural resources were limited by requirements to provide fair compensation for resource nationalizations and the burden of debt. McVeigh and Pahuja approach this history as a conflict between rival modes of jurisdictional action. ${ }^{13}$ The establishment of legal regimes guiding the conduct of the world economy through the Bretton Woods Institutions channeled the expression of a Third World sovereignty into constrained avenues. ${ }^{14}$ Thus, questions of territorial authority need to be understood with relation to the modes of conduct that shape its exercise and how it encounters other forms of legal authority.

Theorizations of jurisdiction have usefully placed state authorities alongside other forms of authority that act beyond or beneath the state. Jurisdiction can be understood as "the exercise by sometimes vaguely defined legal authorities of the power to regulate and administer sanctions over particular actions or people, including groups defined by personal status, territorial boundaries, and corporate membership." "Fundamentally, jurisdictional practice "declares the existence of law and the authority to speak in the name of the law." "Approaching jurisdiction in relation to processes of authorization enables scholars to begin to address the questions of under what law and by which authority.

Colonialism inaugurated new forms of legal authority in spaces where Indigenous peoples already exercised jurisdiction. ${ }^{17}$ Thus, the legal geography of empire "invariably relied on layered legal arrangements within composite polities. ... Many empires assembled political communities boasting divergent constitutional traditions; uneasily maintained overlapping or clashing royal, ecclesiastical, local, and seigneurial jurisdictions; and encompassed a variety of forms and sources of law."18 Moreover, the jurisdictional plurality of colonialism involved not only complex relations between state and Indigenous authorities, but also with corporations. As Philip Stern argues, "the corporation ensured that empire was defined by layers of competing and overlapping jurisdictional authority from its very

11 Shaun McVeigh \& Sundhya Pahuja, "Rival jurisdictions: The promise and loss of sovereignty" in C Barbour \& G Pavlich, eds, After Sovereignty: On the Question of Political Beginnings (London and New York: Routledge, 2010) 97.

12 Georges Abi-Saab, "Permanent Sovereignty over Natural Resources and Economic Activities" in M Bedjaoui, ed, International Law: Achievements and Prospects (Dordrecht: Martinus Nijhoff Publishers, 1991) 597; Nico Schrijver, Sovereignty over Natural Resources: Balancing Rights and Duties (Cambridge: Cambridge University Press, 1997).

13 McVeigh \& Pahuja, supra note 11.

14 Ibid.

15 Lauren Benton \& Richard J Ross, "Empires and Legal Pluralism: Jurisdiction, Sovereignty, and Political Imagination in the Early Modern World" in Lauren Benton \& Richard J Ross, eds, Legal Pluralism and Empires, 1500-1850 (New York and London: New York University Press, 2013) 1 at 6.

16 Shaunnagh Dorsett \& Shaun McVeigh, Jurisdiction (New York: Routledge, 2012) at 4.

17 Shiri Pasternak, “Jurisdiction and Settler Colonialism: Where Do Laws Meet?" (2014) 29:2 Can J Law \& Soc 145.

18 Benton \& Ross, supra note 15 at 1. 
conception." ${ }^{\prime 19}$ While relations between different forms of legal authority have morphed through the years, the condition of jurisdictional plurality has been an enduring feature of the relation between states, corporations, and Indigenous peoples.

To understand how different authorities and modes of authorizing law constitute the conditions of possibility for legal existence, it is necessary to analyze how jurisdiction is exercised. Thus, Dorsett and McVeigh direct inquiry into the technical practices that "create and organize the repertoire of our conduct and hence lawful relations." 20 The technical practices of enacting jurisdiction - such as writing decisions, citing precedents, and drawing maps - serve to define the boundaries of law. Understanding how lawful conduct is ordered in space necessitates "inquiring into the definition of territory itself." 21 The construction of territorial knowledge orients legal practice, enabling authorities to define not only the spatiality of law, but also organize patterns of land use and regulation.

In this paper, I approach the enactment of colonial sovereignty in Gitxsan traditional territories as an effect of jurisdictional practice. I particularly consider the importance of processes of territorialization, corporate authorization, and Indigenous displacement to the articulation of colonial legal orders in British North America. Three features of my approach should be noted. First, rather than focusing on centralized decision-makers, I approach sovereignty in terms of the systems of rationality that organize knowledge about the land and enable the exercise of territorial governance. Second, my approach highlights how the effective operation of sovereign power relates to forms of corporate power. Third, my approach emphasizes the relations between the conduct of colonial territorial jurisdiction and the conduct of pre-existing forms of Indigenous jurisdiction.

\section{GITXSAN LEGAL ORDERS}

Placing the emergence of sovereign regimes in the context of Gitxsan history, it is necessary to begin with the recognition that Indigenous peoples existed as organized societies with their own legal traditions prior to the advent of colonialism in their lives and territories. Aware of the risks associated with locking Indigenous traditions to a timeless notion of cultural authenticity, my intent here is not to catalogue a static definition of Gitxsan legal practice; rather, I aim to flag the distinct forms of authority and modes of conduct associated with the exercise of Gitxsan jurisdiction that would come into (unequal and contested) relationships with colonial authorities. In this section, I provide a brief overview of the conduct of Gitxsan jurisdiction, examining how authority is claimed and rendered effective within Gitxsan legal traditions. ${ }^{22}$ I outline the organization of Gitxsan society into huwilp or house groups. I

19 Philip Stern, “'Bundles of Hyphens': Corporations as Legal Communities in the Early Modern British Empire” in Benton \& Ross, supra note 15, 21 at 21.

20 Dorsett \& McVeigh, supra note 16 at 59.

21 Pasternak, supra note 17 at 149.

22 Speaking of Gitxsan traditions, I want to characterize the shared cultural forms and the dense web of interrelationships that form the foundation of Gitxsan legal orders. This is not, however, to present Gitxsan identity as possessing a transhistorical essence. The central forms of political identification among the Gitxsan, particularly prior to contact with Europeans, were house and clan membership rather than national affiliation. Linguistic differences also cut through the Gitxsan community, which speaks two distinct regional dialects. Gitsenimx is spoken in the contemporary western villages of Gitsegukla, Gitwangak (Kitwanga), and Gitanyow (Kitwancool). Gitsanimx is spoken in the contemporary 
then review how claims to authority by a Gitxsan house, referred to singularly as a wilp, rely upon knowledge of house territories and histories. Finally, I close with a discussion of the conduct of governance through the $y u k w$ or feast hall.

The two primary forms of social organization among the Gitxsan people are wilp and clan membership. ${ }^{23} \mathrm{~A}$ house represents a matrilineal kinship group of approximately thirty families or around one-hundred-fifty people. ${ }^{24}$ Estimates of the current number of huwilp vary but a recent projection placed the number at roughly $62 .{ }^{25}$ Political authority within a house group is associated with a network of hereditary titles, particularly centring on the figure of a hereditary chief. Alongside the hereditary chief, each wilp contains a broad set of ranked titles held by individuals who play a key internal role in wilp governance. Within the structure of Gitxsan governance, the rest of the membership of a wilp holds the status of children, people who could potentially graduate to a ranked name and formal position within the house but have not yet. ${ }^{26}$

Huwilp maintain a horizontal network of relationships throughout the region based on clan affiliations. Each Gitxsan wilp is a member of one of the four larger clans: Ganeda or Lax Seel (Frog), Lax Gibuu (Wolf), Gisgahast (Fireweed), and Lax Skiik (Eagle). Marriages among the Gitxsan are exogamous, with clan members pairing with members of other clans, linking together the broader social fabric of Gitxsan society. Exogamous marriages serve to ensure that families have a web of social supports upon which to rely. Wilp and clan membership is matrilineal, but the wilp and clan of one's father provides support in times of need.

Territories are held by the huwilp. While scholars have often (with laudable political motives) stressed the congruence of these holdings with property in the British common law tradition, there are noble differences. ${ }^{27}$ Presenting the Gitxsan traditional territories as a seemingly analogous structure of territoriality to the concept of property within the British common law has utility to the Gitxsan struggle for recognition in the Canadian legal system. It, however, understates the extent to which the Gitxsan

eastern communities of Kispiox (Ans'pa yaxw), Sik-e-dakh (Glen Vowell), and Gitanmaax, as well as among the descendants of the historic villages of Kisegas and Kuldo. Moreover, as kinship networks connect Gitxsan houses and clans to neighbouring communities, the historical (and contemporary) boundaries of the Gitxsan community have a liminal quality. But there is nevertheless enough commonality to speak of the general characteristics of Gitxsan legal orders.

23 On Gitxsan traditions, see John J Cove, "The Gitksan Traditional Concept of Land Ownership" (1982) 36 Anthropologica 3; Neil J Sterritt et al, Tribal Boundaries in the Nass Watershed (Vancouver: UBC Press, 1998); Margaret Anderson \& Marjorie Halpin, eds, Potlatch at Gitsegukla: William Beynon's 1945 Field Notebooks (Vancouver: UBC Press, 2000); Daly, supra note 1; Richard Overstall, "Encountering the Spirit in the Land: 'Property' in a Kinship-Based Legal Order" in John McLaren, A R Buck \& Nancy E Wright, eds, Despotic Dominion: Property Rights in British Settler Societies (Vancouver: UBC Press, 2005) 22; Mills, supra note 1. Overstall, supra note 23 at 32-33.

25 This estimate comes from Justice McEwan, in Spookw v Gitxsan Treaty Society, 2014 BCSC 1100 at para 120; For a more extended discussion of the shifting number of Gitxsan houses, see, Tyler McCreary, "The Burden of Sovereignty: Court Configurations of Indigenous and State Authority in Aboriginal Title Litigation in Canada" (2014) 17:2 North Am Dialogue 64.

26 Historically, there were also people classed as slaves, who lacked the rights of membership and came under the dominion of a house group as a result of raiding, debt repayment, or gifts.

27 For instance, see Mills, supra note 1 at 90 . "Gitxsan property, like common law property, has to do with the rights of persons to access resources for food, ceremony, and economic pursuits." 
legal conception of territory reflects a distinct mode of relating to the land and conducting lawful relations. As Paul Halliday argues, countering the pervasive norming of state-centred legal orders requires "that we understand the differences between state law and nonstate norms. Then we might explain the interaction between them." 28

For Gitxsan huwilp, the relationship to traditional territories emerges from "the power created by fusing the spirit of a reincarnating human line with the spirit of a specific area of land." ${ }^{29}$ As Ken Muldoe explains,

For us, the ownership of a territory is a marriage of a Chief and the land. Each Chief has an ancestor who encountered and acknowledged the life of the land. From such encounters came power. The land, the plants, the animals and the people all have spirit they all must be shown respect. That is the basis of our law. ${ }^{30}$

The authority of a Gitxsan wilp with respect to its traditional territories referred to as its dax gyet. Understanding the concept of dax gyet requires engagement with Gitxsan processes of constituting authority and conducting lawful relations. In his gloss of the term, Richard Overstall privileges two elements of it: "the chief's initial encounter with the spirit of the land, and the subsequent duty to respect both the human and supernatural partners of the marriage. ${ }^{31}$

The relationship between a wilp and its traditional territories is one of reciprocal stewardship between the house members and "the land and all the life and spiritual energies it contains." leadership of a wilp is expected to maintain knowledge of health of the various plant and animal resources on its territories and effectively steward the land. To maintain this knowledge, wilp members need to be on the land to understand its rhythms. ${ }^{33}$ Gitxsan people historically followed a seasonal round, concentrating around key fishing sites in the fall, and moving out onto the territories to hunt in the winter months.

There is mixed anthropological evidence about historical territorial use and residence patterns, reflecting the complex web of relationships linking members of different huwilp. As wilp members, Gitxsan individuals can access their house territories; through rights referred to as amnigwootx, Gitxsan people can access the traditional territories of their father's wilp while he is alive; through rights referred to as yuugwilatxw, people can also access the traditional territories of their spouse's wilp. ${ }^{34} \mathrm{John}$ Cove

28 Paul D Halliday, "Law's Histories: Pluralisms, Pluralities, Diversity” in Benton \& Ross, supra note 15, 261 at $264-265$.

29 Overstall, supra note 23 at 31.

30 Delgam Uukw, "Delgam Uukw Speaks" in Gisday Wa \& Delgam Uukw The Spirit in the Land (Gabriola: Reflections, 1992) 7 at 7. Ken Muldoe made this statement when he held the name Delgamuukw (as it is conventionally spelled); he has subsequently died and the name is now held by his brother Earl Muldoe.

31 Overstall, supra note 23 at 25.

32 Daly, supra note 1 at 271.

33 Rick Budhwa \& Tyler McCreary, "Reconciling Cultural Resource Management with Indigenous Geographies: The Importance of Connecting Research with People and Place" in Jay T Johnson \& Soren C Larsen, eds, A Deeper Sense of Place: Stories and Journeys of Indigenous-Academic Collaboration (Corvallis: Oregon State University Press, 2013) 195.

34 Mills, supra note 1 at $99-102$. 
portrays an idealized progression of residence for a man of high rank being groomed to eventually hold a chiefly title: "As a child, he will be raised in his patrilocus, but he is expected to reside avunculocally [with his mother's brother] as an adult. After marriage he may live for a brief period of time with his wife's parents, though the couple will ultimately return to his avunculocus." ${ }^{\text {"35 }}$ However, the normative masculinity of Cove's example understates the complexity of the huwilp system. Women could also hold names and responsibility for territory and teaching future generations. Rather than a strict schema of gendered norms about residence, the Gitxsan process of constantly renewing the relationship between the leadership of a wilp and the land required that those in line for a hereditary title spend time on the territory for which they would eventually be responsible.

The dax gyet or authority of a wilp is contingent on the house being able to uphold its responsibilities, renewing its connection with the territories before the broader community. Through the institution of the $y u k w$ or headstone feast, huwilp convey the hereditary leadership of a house, and its authority over its territories, to future generations. Gitxsan hereditary names are thus constantly revitalized through the $y u k w$, as subsequent generations put on the names of their predecessors.

Gitxsan huwilp used practices of public oration as a means to demonstrate their possessions of storied connections to the land, and therefore authority over traditional territories. At a yuwk, a wilp publicly demonstrates their possession of house history and territories through performing the adaawk, the stories of the original encounters with the spirit of the land and successive events in the history of a wilp. As Mary McKenzie, Gyologyet, describes, "Without an [adaawk] you can't very well say you are a chief or you own a territory." ${ }^{36}$ Thus, to publicly demonstrate its authority or dax gyet at the $y u k w$, a wilp puts on display its possession of its adaawk.

Establishing the authority of a wilp over its traditional territories also involves demonstrating the territorial knowledge necessary to steward the lands. Demonstration of territorial knowledge includes a process 'described as 'walking the land' or 'surveying' it and includes naming mountains, rivers, lakes, and other areas. These names are highly descriptive and reflect a detailed knowledge of the landscape." ${ }^{37}$ Territorial names also reflect key events in the history of a wilp and its relationship to its territories.

At the feast, the host wilp would share the resources collected through the management of its territories, further evidencing its knowledge and use of the land. "With the wealth that comes from respectful use of the territory, the House feeds the name of the Chief in the Feast Hall." ${ }^{\text {38 }}$ Sharing food with the assembled community, the wilp demonstrates its commitment to the wise superintendence of its territories and upkeep of its social obligations. Other huwilp witness "the claim to territory, thereby validating the house's ownership of the territory and completing the process of establishing land tenure. ${ }^{39}$ The host wilp provides gifts to its guests in recognition of their work as witnesses. Through

35 John J Cove, "Back to Square One: A Re-Examination of Tsimshian Cross-Cousin Marriage" (1976) 18:2 Anthropologica 153 at 159.

36 Quoted in Daly, supra note 1 at 251.

37 Sterritt et al, supra note 23 at 12.

38 Delgam Uukw, supra note 30 at 7.

39 Sterritt et al, supra note 23 at 12. 
feasting, house members thus publicly perform their identity, and signal possession of their titles and demonstrate fulfillment of their inherited obligations.

The feast system also provides a public forum in which agreements may be formalized. The word for feast, li'ligit, "means to call a gathering where repayments are made."40 During the feast, houses announce any agreements that have been made around land use. ${ }^{41}$ The authority of wilp to enact territorial jurisdiction has been typically embodied within the figure of the hereditary chief, although individuals holding ranked names also at times bear responsibility for stewarding particular sections of the house territory. In the feasts, people formally announce the extension of territorial privileges to the children of male members through amnigwootx and spouses of wilp members through yuugwilatxw. People from outside the wilp can seek permission to use traditional territories, typically offering a form of payment to the hereditary chief responsible. As Gitxsan legality is traditionally performed orally, agreements are announced publicly in the feast, where the hereditary chief of the wilp receiving payment is responsible for acknowledging this payment and clarifying which usage rights have been allocated to whom. Thus, a dynamic system of territorial governance functioned through the institution of the feast.

Through the maintenance of relations within a wilp, between a wilp and its territories, and between huwilp, the Gitxsan people create and maintain the lawful relations governing their territories. However, the conduct of law on Gitxsan territories has been impacted by the introduction of colonialism. Through the imposition of colonial regimes, Gitxsan lands have been reterritorialized as part of the colonial dominion. The reterritorialization of Gitxsan lands in association with the institution of new forms of sovereign and corporate authority has produced new modes of legal conduct that interface with and increasingly come to displace Indigenous legal orders.

\section{MERCANTILISM}

The modern form of sovereignty has its origins in the mercantile period associated with the emergence of imperial trading networks centred on Europe in the sixteenth-century. Through this period, medieval forms of sovereign and corporate authority were reformulated in relation to processes of claiming imperial domains and incorporating Indigenous peoples within forms of imperial rule. In this section, I place the emergence of imperial sovereignty in relation to processes of establishing the geography of empire, authorizing corporate power, and incorporating Indigeneity within the imperial legal architecture of British North America. I begin with a discussion of the cartographic and logistical technologies that enabled the imposition of rule at a distance upon the Pacific North West. I then turn to how the monarchy granted privileges to early modern corporations as decentralized bodies that could effectively move goods to and from the colonies. Finally, I examine the position of Indigenous authorities within the exercise of imperial sovereignty.

With the inauguration of empire, the space of sovereignty fanned out from European capitals and across the globe. The exercise of imperial sovereign authority was only possible through a series of

\footnotetext{
40 M Jane Smith, Placing Gitxsan Stories in Text: Returning the Feathers Guuxs Mak'am Mik'aax (PhD Dissertation, University of British Columbia, 2004) [unpublished] at 169.

41 Mills, supra note 1 at 120. Agreements could reflect either arrangements about past land use or future land use; the requirement was simply one of transparency, as agreements needed to be publicly disclosed.
} 
technological transformations to operationalize rule at a distance. The translation of Indigenous knowledge into new forms of cartographic knowledge constituted the building blocks for producing a new geography of empire. ${ }^{42}$ Through collecting measurements, sketches, and descriptions, colonial agents could contribute to an increasing accumulation of knowledge of empire. In metropolitan centres, imperial officials could collate, classify, compare, and combine knowledge of the colonies. ${ }^{43}$ The knowledge from these explorations could thus be employed to develop subsequent strategies for the conduct of commerce with Indigenous populations.

Travelogues not only catalogued the richness of the environments they encountered, but they described paths through these lands for the fur trade. ${ }^{44}$ The development of transportation corridors that eventually spanned the continent to reach the Pacific Coast was crucial to the emergence of a mercantile empire in British Columbia built on the export of natural resources. ${ }^{45}$ William Brown, a fur trader with the Hudson's Bay Company, first explored Gitxsan territory in the early $1820 \mathrm{~s}^{46}$ He appraised the commercial value of trade with the Gitxsan people, and subsequently Fort Connolly was founded on Gitxsan territory near Bear Lake. Imperial inscriptions of the land as a geography of trade nodes and corridors produced what Jody Berland refers to as "traversed space;" not simply "abstractly quantifiable space, but space that has been mapped and shaped by specific imperial forms of knowledge and administration. ${ }^{, 47}$ Fur trade routes thus formed an essential element through which foreign lands were transformed into imperial peripheries. ${ }^{48}$

The early modern corporations served as a crucial means to extend and remake sovereign power. The construction of empire necessitated the constitution of new forms of authority and modes of conduct in order to operationalize rule at a distance. The corporate charter was a means by which the state sought to recognize the autonomy of corporate bodies in order to harness their power to serve the state. Corporate charters called into being forms of commonwealth, "a typically early modern fusion of private capacities of property ownership and legal personality mixed with the responsibilities and rights to govern over a particular form of public and its well-being. ${ }^{., 49}$ These early corporations were ambiguous entities with "liberties held against the state" in order "to strengthen the state," effectively existing at the liminal

42 Michael Bravo, "Ethnographic Navigation and the Geographical Gift" in David Livingstone \& Charles W J Withers, eds, Geography and Enlightenment (Chicago: University of Chicago Press, 1999) 199.

43 Bruno Latour, Science in Action: How to Follow Scientists and Engineers through Society (Cambridge: Harvard University Press, 1987) at 215-257.

44 Jody Berland, North of Empire: Essays on the Cultural Technologies of Space (Durham: Duke University Press, 2009).

45 Until the early decades of the nineteenth-century, Gitxsan territories remained peripheral to the fur trade. Initially Gitxsan participation in the fur trade was mediated through relationships to coastal Indigenous communities who conducted commerce in a maritime trade with a mix of Russian, British, and American traders. Robert Steven Grumet, "Changes in Coast Tsimshian Redistributive Activities in the Fort Simpson Region of British Columbia, 1788-1862" (1975) 22:4 Ethnohistory 295.

46 James A McDonald \& Jennifer Joseph, "Key Events in the Gitksan Encounter with the Colonial World" in Margaret Anderson \& Marjorie Halpin, eds, Potlatch at Gitsegukla: William Beynon's 1945 Field Notebooks (Vancouver: UBC Press, 2000) 193 at 196.

47 Berland, supra note 44 at 74.

48 Harold A Innis, The Fur Trade in Canada: An Introduction to Canadian Economic History (Toronto: University of Toronto Press, 1999).

49 Stern, supra note 19 at 23. 
boundary between the apogee of a totalizing sovereign power and beginnings of a new form of semiautonomous corporate authority. ${ }^{50}$ Chartering the Hudson's Bay Company, portions of land were placed under the effective control of the corporation so it could facilitate the fur trade and thereby advance of the goals of state.

Formally the imperial sovereign created and supervised the activities of corporations; however, corporate activities on the edge of empire placed them beyond the effective surveillance or control of the sovereign. Acting in the name of the state, corporations developed new techniques of organizing decentralized rule. As Dorsett and McVeigh describe, "in medieval Europe, sovereignty was a personal political denomination, at its highest in the form of the monarch, and based on personal protection and obligation, but without the modern connection to a territorial state unit."51 Granted monopolistic liberties in the name of extending sovereign power to new domains, corporations developed new techniques for managing populations and controlling activities across extensive geographies. ${ }^{52}$ Rather than simply stretching the traditional sovereign authority of the monarch, corporations constructed a new decentralized apparatus of imperial rule that was vital to the jurisdictional plurality of empire.

In its early form there were substantial ambiguities about the status of the corporation as a body acting both on behalf of the sovereign and possessing its own drives - a complex admixture of public powers and private control. In the eighteenth-century, there was no neat separation of politics and economics. As Joshua Barkan describes, corporations were a novel vehicle through which the state sought to recognize the autonomy of particular collectivities in order "to redirect their power toward the fiscal and physical health of the state." 53 They thus represented both the corporate body of the state and the emergence of new diffuse networks through which power could circulate to effectively organize the superintendence and distribution of people and things.

Operationalizing diffuse techniques of rule, corporations began to introduce new processes of ordering conduct. In the mercantile period, imperial sovereigns granted corporations "powers to manage, direct, and channel the conduct of the corporate body, its individual members, and the lives of whole populations." ${ }^{, 54}$ After receiving their charter to exclusive trading rights in 1670, the Hudson's Bay Company served to not only extend British imperial dominion, but also establish and coordinate the fur trade. ${ }^{55}$ The HBC moved manufactured goods from the imperial metropole to the colony, where they were exchanged for furs in the colonial periphery. This required a complex architecture of spatial organization, temporal arrangement, functional specification, and surveillance. "Corporations within colonies were intended to facilitate defense, public expenditure, local government, and justice; they constituted another layer of jurisdiction, legal authority, and site of colonial life." trade, the Hudson's Bay Company organized the spatial distribution of commodities, arranged the

50 Joshua Barkan, Corporate Sovereignty: Law and Government under Capitalism (Minneapolis: University of Minnesota Press, 2013) at 20.

51 Dorsett \& McVeigh, supra note 16 at 35.

52 Barkan, supra note 50 at 19-39.

53 Ibid at 20.

54 Ibid at 28.

55 Innis, supra note 48; Berland, supra note 44.

56 Stern, supra note 19 at 35. 
financing of multi-year exchange cycles, coordinated labour requirements, and operated in accordance with new structures of accountability and oversight.

As the British Crown relied upon corporate institutions to direct the conduct of individuals and populations, the exercise of corporate power erected the scaffolding for new expressions of sovereign territorial authority. Specifically, corporate cartographies developed through the transliteration of knowledge from Indigenous guides gave rise to a visual imagination of territorialized sovereignty. As Jordan Branch has documented, the political mobilization of maps to effect claims to territorial authority found their first meaningful articulation in the colonies, as European imperial authorities projected competing claims to exclusive jurisdiction over trade in colonial territories ${ }^{57}$ Imperial authorities thus used maps to define territorial claims and protect the corporate monopolies established in the name of the state. As Daniel Clayton describes, "British politicians collated and recentred knowledge about the Pacific, and claimed the right to make and hold space for British traders. ${ }^{.58}$ Using cartographies produced through corporate employees' encounters with Indigenous peoples and lands, imperial sovereignties advanced territorial claims against competing imperial interests.

International negotiations over the status of imperial territories served to define the contours of sovereignty. As Antony Anghie has demonstrated, the development of the concept of sovereignty at international law was centrally animated by the project of rationalizing the dispossession of Indigenous populations to secure mercantile flows between the metropole and the colonies. ${ }^{59}$ Nascent doctrines of international law defined sovereignty as the possession of the international family of European empires. Excluded from the international community, Indigenous peoples were denied international personality and domesticated as wards of empire.

The assumption of imperial authority over Indigenous peoples in British North America is evident in the Royal Proclamation of 1763, a document often regarded as the fountainhead of North American Aboriginal rights doctrine. ${ }^{60}$ The Royal Proclamation established that Indian nations living under the asserted protection of the Crown had an exclusive right to any territories they possessed that had not been ceded to the Crown. Following the Royal Proclamation, prior to any expansion of settlements on Indian lands, representatives of the Crown had to call an assembly of the Indian nation concerned and negotiate a price for land surrender. In the absence of such a treaty, the Royal Proclamation forbade colonial governments from granting Indian lands to settlers and required the removal of settlers who implanted themselves on unceded Indian lands. Thus, the British sovereign was situated as the mediator of relations between subjects of the empire settling the colonies and its Indigenous wards qua allies. As Gordon Christie notes, there is a colonial conceit at the heart of the Royal Proclamation as a document that at once recognizes Indigenous land rights and entrenches the authority of the British sovereign to define, encompass, and protect Indigenous rights. ${ }^{61}$

57 Jordan Branch, The Cartographic State: Maps, Territory, and the Origins of Sovereignty (Cambridge: Cambridge University Press, 2013).

58 Daniel Clayton, "The Creation of Imperial Space in the Pacific Northwest" (2000) 26:3 J Hist Geogr 327 at 336.

59 Antony Anghie, Imperialism, Sovereignty and the Making of International Law (Cambridge: Cambridge University Press, 2004) at 13-31.

60 Royal Proclamation, 1763, RSC, 1985, App II, No 1.

61 Gordon Christie, “A Colonial Reading of Recent Jurisprudence: Sparrow, Delgamuukw and Haida Nation” (2005) 23:1

Windsor YB Access Just 17 at 22. 
The substantial debate in the early- and mid-nineteenth century over who possessed sovereignty in the Pacific Northwest centred not on the Indigenous societies already present in the area but competing imperial claims to the territory. ${ }^{62}$ Signing the 1818 Convention of Commerce between Great Britain and The United States of America, and extending the agreement in 1827, British and American jurisdictions overlapped in the first-half of the nineteenth-century. ${ }^{63}$ This jurisdictional overlap remained until the 1846 signing of the Oregon Boundary Treaty set the boundary between American and British domains at the 49th parallel. ${ }^{64}$

In addition to the British and American jurisdictional overlap, imperial practice also exhibited extant forms of jurisdictional plurality involving negotiations with Indigenous authorities in the fur trade. This plurality was not in tension with the aims of the British Crown in the early imperial period, as the fur trade relied upon harnessing the productivity of Indigenous systems of land use. The imperial trade in furs relied on the efficiency of the Indigenous mode of production, and particularly the skill of Indigenous hunters and trappers, including women. ${ }^{65}$ The effective execution of the trade required alliances with Indigenous peoples who did the work of collecting furs. Negotiating these alliances, Hudson's Bay Company employees conducted themselves in accordance with existing Indigenous legal systems. ${ }^{66}$ Traders intermarried with Indigenous women in order to garner status and authority within Indigenous kinship systems. ${ }^{67}$ Traders also regularly followed Indigenous legal traditions in responding to violence, allocating responsibility for transgressions of peaceful relations to kinship networks rather than individuals. ${ }^{68}$

Gitxsan legal traditions thus mediated initial encounters between Gitxsan authorities and imperial agents. As Robin Fisher argues, Indigenous peoples manipulated trading relationships for their own gain. ${ }^{69}$ The fur trade enriched chiefs who were able to capitalize on their position as wardens over

62 Clayton, supra note 58.

63 "Convention of Commerce between Great Britain and The United States of America - Signed at London 20th October, 1818." (1818) 6 Br Foreign State Pap 3; "Convention between Great Britain and the United States of America, relative to the Territory on the North-West Coast of America. - Signed at London, August 6, 1827” (1826) 14 Br Foreign State Pap 975 .

64 "Treaty between Great Britain and the United States of American, for the Settlement of the Oregon Boundary - Signed at Washington, June 15, 1846" (1845) 34 Br Foreign State Pap 14.

65 Contrary to the patriarchal norms of imperial society, gender relations within Indigenous production systems were relatively egalitarian, with women playing a key role in the collection of smaller fur-bearing animals. Sylvia Van Kirk, "The Role of Native Women in the Fur Trade Society of Western Canada, 1670-1830" (1984) 7:3 Front J Women Stud 9.

66 Janna Promislow, “'It Would Only Be Just': A Study of Territoriality and Trading Posts along the Mackenzie River 1800-27” in Lisa Ford \& Tim Rowse, eds, Between Indigenous and Settler Governance (Abingdon and New York: Routledge, 2013) 35.

67 Sylvia Van Kirk, Many Tender Ties: Women in Fur-trade Society, 1670-1870 (Norman: University of Oklahoma Press, 1983) at 28-52.

68 John Phillip Reid, "Principles of Vengeance: Fur Trappers, Indians, and Retaliation for Homicide in the Transboundary North American West" (1993) 24:1 West Hist Q 21. Adopting Indigenous repertoires for responding to murder aided the extension of imperial power, as it enabled corporate agents to avoid a lengthy pursuit of an Indigenous offender and simply kill his most convenient kin.

69 Robin Fisher, Contact and Conflict: Indian-European Relations in British Columbia, 1774-1890, $2^{\text {nd }}$ ed (Vancouver: UBC Press, 1992) at 1-48. 
specific territorial tracts within the Gitxsan legal order. Arthur Ray has noted that fur trade journals paid considerable attention to the norms of Indigenous life that impacted the fur trade. ${ }^{70}$ For instance, William Brown, who established Fort Kilmaurs south of Gitxsan territory on Babine Lake in 1821, described the Indigenous peoples of the Northwest Interior as "men of property" who possessed lands and regulated access to their territories through a kinship structure. ${ }^{71}$ In the early nineteenth-century, fur traders frequently complained about the impact of the traditional mode of Gitxsan territorial governance on pelt yields. Hereditary chiefs closely regulated trapping on their territories, limiting hunting and trapping rights to a few of their house members. ${ }^{72}$

Simultaneously, the fur trade introduced new forms of corporate authority into Indigenous lives. The Hudson's Bay Company sought to manage the activities of their employees as well as the Indigenous populations upon which the trade relied. ${ }^{73}$ While Indigenous peoples still controlled the land, asymmetries of power left Indigenous people increasingly reliant on introduced European goods (such as muskets and ammunition) and unable to repel traders from their forts. ${ }^{74}$ By controlling the fur trade, corporate agents installed new forms of power over Indigenous people, increasingly regulating the activities of Indigenous people to secure maximum returns. Although traders would often conduct themselves in accordance with Indigenous jurisdictional repertoires, following Indigenous traditions in intermarriage and trade, they nonetheless constituted a new form of authority in Indigenous lands. Corporate authorities brought new profit-oriented logics to the conduct of lawful relations in the region. The introduction of corporate traders to Gitxsan territory thus supplemented the exercise of the hereditary chiefs' authority.

Analysis of the mercantile period thus highlights how the effective exercise of imperial sovereignty connects with the construction of geographic knowledge, the authorization of corporate bodies, and the delimitation of Indigenous autonomy. The contours of the sovereign authority of the British Empire during mercantilism differ to a significant degree from what would emerge in settler colonialism. But this early period highlights the jurisdictional plurality of imperialism, and the necessity of dealing with the complex ways in which state, corporate, and Indigenous authorities overlap and interrelate.

\section{SETTLER COLONIALISM}

The emergence of a population of settlers and associated demands for land transformed relationships between sovereign, corporate, and Indigenous authorities. Where mercantilism relied upon harnessing Indigenous systems of production, settler colonialism sought to displace Indigenous peoples from the land; where mercantilism relied on securing routes for the conduct of exchange, settler colonialism

70 Arthur J Ray, "Creating the Image of the Savage in Defence of the Crown: The Ethnohistorian in Court" (1990) 6:2 Native Stud Rev 13 at 15-16.

71 Quoted in Arthur J Ray, "Fur Trade History and the Gitksan-Wet'suwet'en Comprehensive Claim: Men of Property and the Exercise of Title" in Kerry Margaret Abel \& Jean Friesen, eds, Aboriginal Resource Use in Canada: Historical and Legal Aspects (Winnipeg: University of Manitoba Press, 1991) 301 at 303.

72 Ibid.

73 Cole Harris, "Towards a Geography of White Power in the Cordilleran Fur Trade" (1995) 39:2 Can Geogr 131 at 132136 [Harris, Towards a Geography].

74 Ibid at $136-139$. 
reterritorialized the land itself as a resource to exploit; where mercantilism used corporations as a vehicle to extend sovereign power, settler colonialism reimagined corporations as private entities operating in an economic domain distinct from the political domain of sovereign authority. In this section, I review how settler colonialism reimagined the conduct of sovereign governance, dispossessing Indigenous peoples through the impositions of new modes of territorial regulation that enabled the corporate exploitation of the land as resource.

Empirically, I centre this scission on the transformation of the wilderness into the foundation of a productive forest economy in the first half of the twentieth-century. ${ }^{75}$ Using forestry as an example of the effects of settler colonialism on the Gitxsan people, I highlight three changes. First, the establishment of new regimes of forest use required the displacement of Indigenous tenure systems. The goal was no longer intercourse with Indigenous modes of production but to install new modes of using the land. Second, the materialization of new land uses required new forms of knowledge. Developing the regulatory knowledge to manage this forest use was now clearly an exercise of state authority (rather than an exercise of corporate authority on behalf of the state). The adoption of scientific forest management by agents of the state reconfigured knowledge about how the forest should be used and how forest governance could be conducted. Third, there was increasing dependence upon large forestry companies, now clearly imagined as private enterprises operating in the market, to mobilize economic activity. While corporations were, as before, imagined as a vehicle to advance the public good, they now were imagined to do so as private actors in an economic domain external to the state.

In contrast to the imperial legality that asserted forms of jurisdiction over Indigenous bodies participating in the fur trade, settler colonialism radically territorialized the exercise of sovereignty to institute regimes of governing relationships to the land itself. While mercantilism relied upon Indigenous land use to produce furs, settler colonialism expropriated the land base from Indigenous people as the foundation for capitalist extractive resource economies. ${ }^{76}$ As Cole Harris expresses the matter, "capitalism works to deterritorialize people (that is, to detach them from prior bonds between people and place) and to reterritorialize them in relation to the requirements of capital (that is, to land conceived as resources and freed from the constraints of custom and to labor detached from land)." the context of settler colonialism, the primary object "is the land itself rather than the surplus value to be derived from mixing native labour with it." 78

In the period between the formation of the colony of British Columbia in 1858 and its union with the Canadian confederation in 1871, colonial authorities did not treaty with Indigenous peoples. The establishment of the British Columbia colony in 1858, following the arrival of gold-seeking migrants, reoriented practices of government away from a distant metropolitan sovereign and towards the interests

75 This formulation of the problematic of transforming wilderness to territorialized provincial forests is taken from David A Rossiter, "Producing Provincial Space: Crown Forests, the State and Territorial Control in British Columbia" (2008) 12:2 Space Polity 215.

76 Glen S Coulthard, Red Skin, White Masks: Rejecting the Colonial Politics of Recognition (Minneapolis and London: University of Minnesota Press, 2014) at 9-15.

77 Cole Harris, "How Did Colonialism Dispossess? Comments from an Edge of Empire" (2004) 94:1 Ann Assoc Am Geogr 165 at 172 [Harris, "Comments"].

78 Patrick Wolfe, Settler Colonialism and the Transformation of Anthropology: The Politics and Poetics of an Ethnographic Event (London and New York: Cassell, 1999) at 163. 
of the collective settler 'people.' There were some early experiments with treaty-making in the independent colony of Vancouver Island (which formed first in 1849, merging with British Columbia in 1866). ${ }^{79}$ However, the colony of British Columbia simply circumscribed Indigenous space within the confines of illiberally allocated reserves, circumventing the question of Indigenous title. ${ }^{80}$ As articulated by the Chief Commissioner of Lands and Works, Joseph Trutch, in 1870, "[t]he title of the Indians in the fee of the public lands, or any portion thereof, has never been acknowledged by Government, but, on the contrary, is distinctly denied."

Although British Columbia practice contravened the established Canadian norms in which colonial authorities used treaties with Indigenous peoples to secure a legal foundation for the colonial state, the Dominion government permitted the continuation of anomalous British Columbia practice. With regard to Indian land policy, Article 13 of the British Columbia Terms of Union stated that "a policy as liberal as that hitherto pursued by the British Columbia Government shall be continued by the Dominion Government after the Union." ${ }^{\prime 82}$ Although the phrasing miscast the conduct of the colony of British Columbia as "liberal," the Terms of Union provided the grounds for continued disregard to Indigenous title claims within the province. Though the continuation of British Columbia policy clearly violated the dictates of the Royal Proclamation of 1763, the province and federal government continued to allocate reserves without addressing Indigenous title.

In the provincial north, the allocation of Gitxsan reserves occurred under reserve commissioners jointly appointed by the provincial and federal government. In 1891, the Indian Reserve Commissioner, Peter O'Reilly first arrived in the region to begin laying out reserves. ${ }^{83}$ The principal villages reserved for the use of the Gitxsan were at Kisegas, Kuldo, Kispiox (Ans'pa yaxw), Sik-e-dakh (Glen Vowell), and Gitanmaax, in the east of their territories, and Gitsegukla, Gitwangak (Kitwanga), and Gitanyow (Kitwancool) in the West. A Witsuwit'en village, Hagwilget (Tse-Kya), used to access key fishing sites on Gitxsan territory was also reserved. ${ }^{84}$ The population of Kisegas and Kuldo would later be relocated to Gitanmaax and Kispiox. In association with the reserve system, the Indian Act imposed a political system of band governance to replace the traditional system of feast governance. ${ }^{85}$ With the introduction of the band system and criminalization of feast governance, the traditional mode of conducting Gitxsan territorial governance was forced underground.

Settler colonialism introduced new patriarchal gender relations. While Gitxsan people traditionally followed matrilineal definitions of wilp membership, the Indian Act relied upon patrilineal forms of regulating identity, excluding women who married non-Indians and their descendants from Indian

\footnotetext{
79 Tennant, supra note 2 at 17-25; Harris, Making Space, supra note 2 at 18-30.

80 Tennant, supra note 2 at 26-43; Harris, Making Space, supra note 2 at 31-69.

81 Quoted in Tennant, supra note 2 at 39.

82 Order of Her Majesty in Council admitting British Columbia into the Union, dated the 16th day of May, 1871.

83 Mills, supra note 1 at 49-50.

84 Maureen Cassidy, The Gathering Place: A History of the Wet'suwet'en Village of Tse-Kya (Hagwilget BC: Hagwilget Band Council, 1987).

85 Douglas Cole \& Ira Chaikin, An Iron Hand upon the People: The Law Against the Potlatch on the Northwest Coast (Vancouver: Douglas \& McIntyre, 1990).
} 
status. ${ }^{86}$ Settler colonial legislation made Indigenous women subject to conventional Victorian family ideals, "with the husband as the controlling partner and the wife under his dominance." 87 Moreover, Indigenous women, once valued in the fur trade, were now subject to disciplinary controls to control racial intermixing. ${ }^{88}$

Through the early twentieth-century, white settlers and land speculators began to move into Gitxsan territories. ${ }^{89}$ Settlers established farms and fences, and built the first sawmills in the region, protected by the veil of colonial law. As Cole Harris notes, this new geography of fences, roads, and railways, of farms and sawmills, of industrial camps and towns, installed the most pervasive disciplinary technology. ${ }^{90}$ Superimposed on Indigenous territories, this new geography of settlement and development worked to redefine the space. It established which areas were appropriated for the project of settlement and development, and which areas were still available for Indigenous use.

When the Gitxsan resisted dispossession, their dissent was directed into bureaucratic channels or criminalized. $^{91}$ In the early-twentieth-century, the Gitxsan mobilized to advance land claims. In 1908, Gitxsan and other Indigenous chiefs visited the Prime Minister with a land rights petition, and Gitxsan people in Gitwangak blocked surveyors, demanding a meeting to address land issues. ${ }^{92}$ The Indian agent promised a commission to diffuse mounting tension, yet the Stewart-Vowell Commission in 1909 resolved little. ${ }^{93}$ In June of 1909 at Kispiox, the chiefs posted notices forbidding whites from crossing the river, and in November, Kispiox chiefs blocked a road construction crew at gunpoint and seized their equipment. ${ }^{94}$ Seven Gitxsan men were arrested in a subsequent raid of the community. The Gitxsan sent another petition to Laurier, and were included in the McKenna-McBride Commission's review of the Indian land question from 1913 to 1916; however, provincial opposition to addressing Indigenous title issues continued to limit discussions. ${ }^{95}$ Finally to resolve the question of Indigenous title, the Canadian government introduced a 1927 Indian Act amendment that made it illegal for Indians to organize around land claims, and banned lawyers from working on such cases.

Alongside the dispossession of Indigenous peoples, the provincial government sought to install new forms of territorial control and resource governance. As Patrick Wolfe describes, settler colonialism had destructive and constructive dimensions: "Negatively, it strives for the dissolution of native societies. Positively, it erects a new colonial society on the expropriated land base." 96 Developing new state

86 Bonita Lawrence, "Real” Indians and Others: Mixed-Blood Urban Native Peoples and Indigenous Nationhood (Vancouver: UBC Press, 2004) at 45-63; Mary Eberts, "Victoria's Secret: How to Make a Population of Prey" in Joyce Green, ed, Indivisible: Indigenous Human Rights (Halifax: Fernwood, 2014) 144.

87 Eberts, ibid at 151.

88 Renisa Mawani, Colonial Proximities: Crossracial Encounters and Juridical Truths in British Columbia, $1871-1921$ (Vancouver: UBC Press, 2009) at 163-200.

89 R Geddes Large, Skeena: River of Destiny (Vancouver: Heritage House, 1996) at 49-61.

90 Harris, "Comments", supra note 77 at 179.

91 Galois, supra note 3.

92 Ibid at 145.

93 Mills, supra note 1 at 51.

94 Galois, supra note 3 at 149.

95 Harris, Making Space, supra note 2 at 228-248.

96 Patrick Wolfe, "Settler Colonialism and the Elimination of the Native" (2006) 8:4 J Genocide Res 387 at 388 [Wolfe, "Settler Colonialism"]. 
apparatuses of territorialized sovereign rule, the settler state adopted from the early imperial corporation the decentralized model of superintending the distribution of people and resources. ${ }^{97}$ Thus, from the latenineteenth through the mid-twentieth century a fundamentally different state regime emerged in British Columbia. Where under mercantilism the state relied upon corporate bodies to exercise authority over relations in distant territories, under settler colonialism a more robust state apparatus with its own forms of territorial knowledge began to emerge. Conceptual splits between corporate and state domains served as central mechanisms for organizing relations. Applying regulatory authority, state legislators and policymakers focused on establishing procedural norms to guide corporations in the conduct of productive relations. Thus, regimes of corporate resource extraction were both legally constituted through and regulated by emergent forms of territorial knowledge.

To reconfigure and regulate the use of the land for resource extraction, new forms of resource knowledge had to be constructed. As Bruce Braun argues, the imagined economic potential of the land relates to scientific discourses about the qualities of that land, and scientific discourses about natural resources constitute the basis for political rationalities of resource governance. ${ }^{98}$ Scientific representations of natural resources shaped perception of possibilities for development and interlinked with the articulation of regimes to regulate the best use of natural resources. Thus, knowledge of forestry is a key element in constituting how forests are integrated into circuits of political regulation and economic production. ${ }^{99}$ Forest science established not only new ways of thinking about trees, but fundamentally altered regimes of forest production and forest governance. ${ }^{100}$

The British Columbia Royal Commission of Inquiry on Timber and Forestry of 1909-1910 was the first scientific review of forest resources and management practices in British Columbia. Previously forest use had been regulated incidentally through different pieces of legislation, principally under the Department of Lands. ${ }^{101}$ In response to concerns about the chaotic organization of forestry, the Premier tasked the commissioners with investigating the timber resources of the province and the best mechanisms to ensure their effective use and conservation. Through the Commission, the government began to develop new regulatory capacities associated with scientific knowledge of the forest. The Commission recommended the formation of a government department dedicated to the efficient management of public forests. ${ }^{102}$ In 1912, the province introduced the first Forest Act and formed the Forest Branch. ${ }^{103}$

97 Barkan, supra note 50 at 41-64.

98 Bruce Braun, "Producing Vertical Territory: Geology and Governmentality in Late Victorian Canada" (2000) 7:1 Cult Geogr 7.

99 David Demeritt, "Scientific Forest Conservation and the Statistical Picturing of Nature's Limits in the Progressive-Era United States" (2001) 19:4 Environ Plan Soc Space 431; Bruce Braun, The Intemperate Rainforest: Nature, Culture, and Power on Canada's West Coast (Minneapolis: University of Minnesota Press, 2002); Rossiter, supra note 75.

100 James C Scott, Seeing Like a State: How Certain Schemes to Improve the Human Condition Have Failed, Yale Agrarian Studies (New Haven: Yale University Press, 1998) at 11-52.

101 Rossiter, supra note 75.

102 Ibid.

103 An Act respecting Forests and Crown Timber Lands and the Conservation and Preservation of Standing Timber, and the Regulation of Commerce in Timber and Products of the Forest, SBC 1912 c 17. 
The Forest Branch sought to organize forestry to the benefit of the province by regulating forest use. The development of the forest as a discursive object through the early twentieth-century provided a new language in which the forest could be imagined as bounded and subject to scientific, and thus, political management. As David Rossiter details, the Commission stressed the necessity of "adopting the best practices available in scientific forestry" so that the province might "take both control of its birthright and to draw a bright provincial future out of its deep forests." ${ }^{\text {"104 }}$ Forest Branch agents surveyed the provincial forests, and developed a model for regular cycles of controlled harvest, regrowth, and subsequent re-harvest. The overriding objective was to develop a regime of rationalized management that could be managed by settler colonial bureaucrats.

The commitment to using scientific management principles to guide the efficient harvest of forest resources endured in two later Royal Commissions on Forestry headed by Chief Justice Gordon Sloan. The appointment of the Sloan Commissions was triggered by the recognition that provincial forests were being over-harvested and the sustainability of the forest economy was in jeopardy. There were also concerns about the need to instill greater predictability and stability within an industry characterized by boom-and-bust cycles. Addressing these concerns in reports in 1945 and 1956, Sloan reiterated the necessity of maximizing the value derived from public forests through regulatory interventions to ensure both sustained-yield management and the profitability of existing private enterprises engaged in forestry. ${ }^{105}$

The ideal of sustained-yield forest management aimed to convert natural forests into scientificallymanaged "normal" forests. The normal forest represented "an ideally constituted forest with such volumes of trees of various ages so distributed and growing in such a way that they produce equal annual volumes of produce which can be removed continually without detrimental impacts to future production." "106 Borrowing an agricultural model of socio-natural cycles of production, in principle the management of the normal forest aims to establish a prescribed harvest rotation of blocks of evenly-aged commercial tree species to enable a constant rate of production. The normal forest "promised to deliver not only the highest wood volumes in constant increments over time, but also a measure of economic and administrative stability and predictability." ${ }^{107}$ On the basis of the public economic good, the Sloan Commission rationalized replacing ecologically diverse natural forests with managed "normal" forest monocultures. Thus, as Prudham describes, forestry discourse portrayed natural forests and particularly old growth forests as inefficient, and better replaced with scientifically-managed monocultural forests. ${ }^{108}$ In the wake of Sloan's first report, the province introduced a system of sustained yield management. ${ }^{109}$

In his two commissions, Sloan sought to develop strategies to provide more security to corporate forestry operations as a means of maximizing the stability of forest economies. Specifically, Sloan advanced the transformation of temporary forest tenures to forms of tenure that permitted the operator to

\footnotetext{
104 Rossiter, supra note 75 at 223.

105 Gavin Bridge \& Phil McManus, "Sticks and Stones: Environmental Narratives and Discursive Regulation in the Forestry and Mining Sectors" (2000) 32:1 Antipode 10; Scott Prudham, "Sustaining Sustained Yield: Class, Politics, and PostWar Forest Regulation in British Columbia” (2007) 25:2 Environ Plan Soc Space 258.

Ibid at 263-266.

109 An Act respecting Crown Timber and the Conservation and Preservation of Forests, RSBC 1948, c 128.
} 
retain long-term possession of the forest. Sloan embraced providing secure land access to companies through a system of area-based or volume-based tenures, referred to respectively as Forest Management Licenses (later Tree Farm Licenses) and Forest Licenses. ${ }^{110}$ Thus, corporations gained exclusive rights (though term-limited) to appropriate the resources of public lands. Imagining that larger corporations were more stable, the province came to favour larger firms in awarding licenses. ${ }^{111}$ This approach to governance reflected the normalization of new modes of regulation associated with a political economic rationality that sought to regulate private actors' economic activity as a means to secure the public good. The conception of the public good as served by corporations as private actors in the economic domain contrasted with the mercantile period in which the corporation had been imagined as an apparatus of state.

From the absolutization of state power in the early-modern period, the development of liberal legal doctrines of public and private spheres heralded "the introduction of the restrictive principle in governmental practice." ${ }^{, 12}$ With the rise of capitalism, a new rationality of governance emerged alongside the idea of the economy as a distinct domain. "Political sovereignty was split off from the economy," as Susan Buck-Morss expresses the matter, "its internal logic depended on the exclusion of the economy from any visible position within the imaginary political terrain." 113 The economy - now imagined as a distinct domain with its own internal logics - was recast as the most effective means to secure public welfare. The role of government within the liberal imagination was to establish "a stable set of legal norms that would enable people to govern themselves economically and through the economy." 114 The fabric of society had been fundamentally reimagined with a decentralized network of exchange and contracts binding actors together rather than an encompassing state. This opened the economy to a new global sphere, no longer dependent on an imperial geography and instead secured by an emergent global legal order protecting the privately held property rights cognizable within the categories of settler colonial law. ${ }^{115}$

The corporation was thus fundamentally reconfigured - no longer a body acting in the name of the state but now a private actor in the economic domain beyond state authority. In the mercantile period, the sovereign chartered corporations served to enhance the totalizing power of the state, whose interests were presented as synonymous with broader society. As Barkan documents, even with early-nineteenthcentury American corporations, there was a presumption the companies would "directly reinforce the public welfare." 116 However, by the twentieth-century, the corporation had reconsolidated as a private economic actor, now imagined as a vehicle that would advance the public good by following a private profit-making motive.

110 Bridge \& McManus, supra note 105; Prudham, supra note 105.

111 Prudham, supra note 105.

112 Michel Foucault, The Birth of Biopolitics, Lectures at the College de France, 1978-1979, translated by Graham Burchell, Michel Senellart et al, eds. (Houndmills: Palgrave Macmillan, 2008) at 22. In his lectures, Foucault placed the point of origins of this transformation in the eighteenth-century.

113 Susan Buck-Morss, Dreamworld and Catastrophe: The Passing of Mass Utopia in East and West (Cambridge: MIT Press, 2002) at 15.

114 Barkan, supra note 50 at 57.

115 Notably, in this period, this still did not include the property held within Indigenous legal orders in British Columbia.

116 Barkan, supra note 50 at 57. 
The close and ambiguous relation between the state and corporation dissipated with the development of capitalist economic relations. Where the Hudson's Bay Company had been granted privileges to advance the interests of the sovereign, forestry companies were granted private rights in order to advance a public good conceptualized in economic terms through the market. Rather than an entity granted privileges to act in the interest of the sovereign, corporations gained personhood to privately act in the economic domain. The corporation became a distinct entity from the sovereign and its shareholders. "Instead of encouraging improvement by granting monopolies, general incorporation laws promoted investment by making limited liability a normal aspect of the corporate form."117 Undergirding the emergent orientation of corporate law was the notion that private actors could best organize the productive relations of society, and that corporate forms of private action were required to achieve the economies of scale necessary to maximize economic efficiency and stability. Thus, the grant of corporate rights, alongside the increasing concentration of economic power, was justified as necessary for economic security. ${ }^{118}$

The development of settler colonialism thus established new forms of private corporate authority as it constricted the space of Indigenous autonomy. Settler colonialism differed from earlier imperial regimes as it targeted possession not of resources produced through Indigenous economies, but instead, of the land itself. Regimes of Indigenous dispossession thus necessarily paralleled the reterritorialization of the land as a resource regulated by the state to ensure the stability of regimes of corporate appropriation. The reterritorialization of the forest and field, mountain and stream, as potential resources for regimes of capitalist development would radically remake the land imaginatively and materially. However, the majority of Indigenous peoples in British Columbia never ceded their lands and continued to struggle against their dispossession as regimes of resource extraction intensified.

\section{INDIGENOUS RESURGENCE}

The contemporary Indigenous rights movement had its beginnings in the late 1960s and intensified in the decades that followed, legally challenging the exclusions of settler colonial sovereignty. The Gitxsan hereditary chiefs were major actors in this political resurgence, bringing to trial in 1987 a case for ownership of and jurisdiction over their unceded traditional territories. Challenging settler colonial jurisdiction in court, the Gitxsan hereditary chiefs unsettled the colonial territorializations underlying development. In 1997, the Supreme Court of Canada, recognizing the salience of this challenge, established the necessity of reconciling the historical claims of Indigenous peoples with the settlement and development of the land. In subsequent decisions, the Supreme Court clarified that duties to Aboriginal peoples only applied to the sovereign not corporations. However, court victories did not open consideration to the fullness of Indigenous traditions; instead the court positioned Indigeneity within a naturalized colonial order.

Through the 1970s and 1980s, the Indigenous peoples in Northwestern British Columbia had sought to advance land claims to secure recognition of their land rights. In 1967, the Nisga'a people had brought suit in Calder v. British Columbia, asking the court to declare that Aboriginal title to their lands

117 Ibid.

118 Ibid at 44. 
had not been lawfully extinguished. When the case was decided in the Supreme Court of Canada in 1973, the Justices recognized that Aboriginal title existed prior to colonization, but split on whether it had been extinguished by virtue of the exercise of colonial sovereignty over the lands in question, with the deciding judge ultimately dismissing the case on a legal technicality. ${ }^{119}$ The decision triggered the development of a federal comprehensive land claims process to address unresolved Indigenous land claims. $^{120}$

Working within a new legal environment created by the Supreme Court's in-principle recognition of Aboriginal title in the Nisga'a's case, a federation of Gitxsan and Witsuwit'en Indian Act bands, operating under the name of the Gitksan-Carrier Tribal Council, entered land claims negotiations in $1977{ }^{121}$ The ambiguity of the Calder decision, however, enabled the provincial government - who claimed jurisdiction over the majority of Gitxsan and Witsuwit'en lands - to maintain that Aboriginal people had no contemporary claim to title. ${ }^{122}$ While the federal government was willing to negotiate with the Gitksan-Carrier Tribal Council, the province stymied negotiations, refusing to consider Indigenous political claims that effectively extended beyond those of a municipality. With the path forward blocked, the Gitxsan and Witsuwit'en turned to the courts. Eschewing the band council governing structures created under the Indian Act, the Gitxsan and Witsuwit'en decided to advance their claims in the name of the traditional hereditary authorities, which had continued to govern traditional territories and the passage of hereditary titles in parallel with the imposed Indian Act governance of reserve life. ${ }^{123}$ Delgamuukw v British Columbia began trial in the British Columbia Supreme Court in 1987 and concluded with the Supreme Court of Canada in $1997 .{ }^{124}$

In Delgamuиkw, the Gitxsan and Witsuwit'en hereditary chiefs presented the court with a claim to ownership of and jurisdiction over their traditional territories based on their own systems of law. Prior to going to court, the hereditary chiefs met and agreed to a map outlining their respective territories. ${ }^{125}$ The chiefs claimed 133 separate territories, representing an aggregate 58,000 square kilometers of British

119 Calder et al $v$ Attorney-General of British Columbia [1973] SCR 313, 4 WWR 1.

120 In fact, the federal Liberal government of the period completely reversed their stance on Aboriginal title and rights in the wake of the decision, abandoning their program for the dissolution of the Indian Act and the removal of legal recognition of Indian Status. Sally M Weaver, Making Canadian Indian Policy: The Hidden Agenda, 1968-70 (Toronto: University of Toronto Press, 1981) at 189.

121 The Gitksan-Carrier Tribal Council included the Gitxsan bands of Gitsegukla, Kitwanga, Kispiox, Glen Vowell, and Gitanmaax, as well as the Witsuwit'en bands of Hagwilget and Moricetown. Kitwancool was not included and never became a party to the land claims litigation to follow. Now referred to as Gitanyow, it remains distinct from the rest of the Gitxsan community.

122 Mills, supra note 1 at 62.

123 Their decision to advance their case on the basis of Indigenous traditional authorities rather than Indian Act bands has given a different shape to relations between Gitxsan, state, and corporate authorities. Where in many instances, state and corporate authorities interact with Indian Act bands as the representative authority for Indigenous peoples racialized as Indians, the standing of the hereditary chiefs in the Delgamuиkw case established their legitimacy as representatives of their people. For an extended discussion of this aspect of the litigation, and its enduring political effects in relations between the Gitxsan hereditary chiefs, corporations, and the state, as well as Indian Act bands, see McCreary, supra note 25.

124 Delgamuukw v British Columbia [1997] 3 SCR 1010, 153 DLR $\left(4^{\text {th }}\right) 193$ [Delgamuukw 1997].

125 Matthew Sparke, “A Map that Roared and an Original Atlas: Canada, Cartography, and the Narration of Nation" (1998) 88:3 Ann Assoc Am Geogr 463 at 473. 
Columbia. In court, Gitxsan hereditary chiefs served as expert witnesses demonstrating the vitality of their laws. ${ }^{126}$ Initially, Gitxsan and Witsuwit'en hereditary chiefs' appeal to the courts appeared to consolidate colonial authority as the judges at the trial and appellant courts disavowed the value of the hereditary chiefs' evidence and the legitimacy of Gitxsan and Witsuwit'en positions. ${ }^{127}$ The majority of the Supreme Court of Canada, however, overturned the lower court decisions and ordered a retrial on the basis of the mishandling of evidence at trial. ${ }^{128}$

The Justices of the Supreme Court of Canada established an important precedent requiring the government to consider Indigenous knowledge and negotiate with Indigenous peoples. Particularly the court clarified that Indigenous legal traditions, such as the adaawk the Gitxsan hereditary chiefs brought into court, were a valid form of evidence in establishing proof of Aboriginal title. Further, while the court did not decide on the particular Gitxsan and Witsuwit'en claim at issue, the Justices did recognize the existence of the concept of Aboriginal title at common law. Giving Aboriginal title shape, the Justices delineated the content of the concept under Canadian law. Although the Justices would not say if the Gitxsan and Witsuwit'en possessed it, Aboriginal title was now clearly a recognizable Canadian legal concept.

Explicitly the decision urged the Canadian and provincial governments to negotiate with Indigenous peoples regarding the unresolved question of land title in British Columbia. While the Supreme Court of Canada decision on Delgamuukw offered the Gitxsan and Witsuwit'en hereditary chiefs no immediate remedy, it significantly contributed to the emergence of new regimes of engagement and new devices to reconcile the exercise of colonial power with Indigenous peoples and their interests.

Based on the precedent established in Delgamuukw, in 2014 the Supreme Court of Canada issued its first finding of Aboriginal title in Tsilhqot'in Nation v. British Columbia, setting an imposing standard for governments when considering developments on Aboriginal title lands. ${ }^{129}$ In cases where an Indigenous people possess proven title and do not consent to development, the government must justify infringement and prove it has upheld its fiduciary duties to the Indigenous people in question. To justify infringement, the government must demonstrate that the abridgement of Aboriginal rights and title serves a compelling and substantial governmental objective. The government is further required to honorably act to uphold the interests of Indigenous peoples. To uphold its fiduciary duties, the government must demonstrate that infringement is necessary to achieve the state aim, that the incursion goes no further than necessary to achieve the government's goals, and that the benefits flowing from the development are not outweighed by the adverse impacts on Aboriginal interest caused by infringement. Moreover, government decision-making must respect that Indigenous interest in Aboriginal title lands inheres in both present and future generations. Thus, infringements cannot be justified if such incursions would substantially deprive future generations of the benefit of the land.

126 Robin Ridington, "Fieldwork in Courtroom 53: A Witness to Delgamuukw" in Frank Cassidy, ed, Aboriginal Title in British Columbia: Delgamuukw v The Queen (Lantzville \& Montreal: Oolichan Books \& The Institute for Research on Public Policy, 1992) 206; Culhane, supra note 3. Delgamuukw v British Columbia, [1991] 79 DLR (4th) 185 (BCSC); Delgamuukw v British Columbia, [1993] 104 DLR (4th) 470 (BCCA).

128 Delgamuukw 1997, supra note 124.

129 Tsilhqot'in Nation v British Columbia, [2014] SCC 44. 
In cases where Indigenous peoples have asserted title but have yet to have its existence established by court declaration or agreement, the government is required to consult in good faith and accommodate the interests of claimant groups where necessary. In the 2004 case Haida Nation v British Columbia, Chief Justice Beverley McLachlin, writing for a unanimous court, found that the Canadian sovereign has a "duty to consult with Aboriginal peoples and accommodate their interests." ${ }^{.130}$ However, while the Supreme Court suggested the colonial government must act in good faith through consultation, they also burdened Indigenous counter-claims with a requirement to remain reasonable in their participation in the exercise of consultation. Thus, Indigenous peoples were refused the possibility of simply deciding against a given development project, as such a position could be construed as an unreasonable attempt to thwart development and a violation of the requirement to participate in consultations in good faith. Canadian jurisprudence has not recognized Indigenous peoples as possessing the inherent authority to decide against development.

Moreover, in Haida Nation the court refused the suggestion that corporations may also share in the obligation to consult Indigenous peoples. The court registered that corporations have regularly served a role in mobilizing the knowledge necessary for territorial government, but bracketed their responsibility. "The Crown may delegate procedural aspects of consultation to industry proponents seeking a particular development; this is not infrequently done in environmental assessments." ${ }^{, 131}$ Thus, the court replied upon and reproduced the foundational split between the political and economic domain. Despite the role of corporations as a vehicle mobilizing knowledge for resource governance - and subsequently profiting from resource development - the courts have insulated them from the political responsibilities of the state's relationship to Indigenous peoples. Quoting McLachlin, "the duty to consult and accommodate ... flows from the Crown's assumption of sovereignty over lands and resources formerly held by the Aboriginal group. This theory provides no support for an obligation on third parties to consult or accommodate." ${ }^{132}$ Thus, Indigenous challenges only burden the sovereign, and it is the political and legal obligation of the sovereign to secure the territorial basis of development. As such, the court maintained the normative separation of the political and economic sphere, a division instituted through colonial forms of organizing knowledge and relationships.

While Indigenous legal claims challenged state authorities, who possessed a legal responsibility to uphold its duties with regard to Indigenous peoples, these challenges nonetheless impacted corporate development proponents. While the legal particularities of the relationship between colonial state authority and Indigenous peoples do not require corporate engagement with Indigenous peoples, the uncertainty generated by legal recognition of Aboriginal title has made it necessary for industry to develop strategies to resecure investments in resource development. The court in Tsilhqot'in Nation advised that "Governments and individuals proposing to use or exploit land, whether before or after a declaration of Aboriginal title, can avoid a charge of infringement or failure to adequately consult by obtaining the consent of the interested Aboriginal group." ${ }^{, 133}$ Regulative pressure works through a legal regime that acts not to decide the course of development but rather cast a shadow framing

\footnotetext{
130 Haida Nation v British Columbia (Minister of Forests), [2004] 3 SCR 511, 2004 SCC 73 at para 16.

131 Ibid at para 53.

132 Ibid.

133 Tsilhqot'in Nation v. British Columbia, supra note 129 at para 97.
} 
negotiations. ${ }^{134}$ The recognition (or potential recognition) of Aboriginal title thus works to establish an incentive for negotiations. In the context of Indigenous contestation of development projects, the legal recognition of Aboriginal rights and title fosters engagement between Indigenous peoples and industry. So long as developers can address Indigenous interests, development can proceed, typically on the basis of incorporating mechanisms to provide Indigenous communities with compensation, to share revenue, or to provide access to training and jobs.

\section{CORPORATE RECONCILIATION}

To ensure greater predictability in their investments, corporations have now developed practices to contract with Indigenous communities. These agreements provide an avenue for development to progress in the absence of treaties between the state and Aboriginal people securing the legal status of land. Avoiding the lacunae of Canadian jurisprudence in the areas of Aboriginal rights and state obligations, corporations have drawn upon the traditions of contract law as a basis for agreements. Corporations that are extracting resources from Indigenous territories are now negotiating directly with Indigenous authorities. While corporations still have to be entitled to operate within the province's jurisdiction under provincial law, they no longer defer to the state to secure Indigenous consent. ${ }^{135}$ As the state has been displaced as a mediator of relationships between private actors and Indigenous peoples, corporate-Indigenous agreements represent a significant reformulation of relations.

The use of private contracts to secure Indigenous support for resource development represents a significant modification in relations between state, corporate, and Indigenous authorities. Proponents of negotiated corporate-Indigenous agreements present them as decolonizing mechanisms, bringing Indigenous peoples out from under the apron of the colonial state. ${ }^{136}$ For instance, Jean Michel Montsion argues that the Indigenous strategy of directly contracting with transnational corporations expresses a radical form of Indigenous sovereignty that functions to "disrupt and interrupt the hegemonic norm of Westphalian state sovereignty and create space for the inclusion and conduct of autonomous indigenous political life." ${ }^{137}$ However, rather than replacing the settler colonial political economy, practices of corporate-Indigenous contracting channel the conduct of Indigenous life into the structure of colonial legal frameworks. Unlike fur trade negotiations, which followed Indigenous custom, contemporary corporate-Indigenous contracts reflect the traditions of colonial corporate law.

134 On how legal frameworks direct economic processes in capitalist society, see Robert L Hale, "Coercion and Distribution in a Supposedly Non-Coercive State" (1923) 38:3 Polit Sci Q 470; On bargaining in the shadow of the law, see Robert H Mnookin \& Lewis Kornhauser, "Bargaining in the Shadow of the Law: The Case of Divorce" (1979) 88:5 Yale LJ 950.

This is, of course, only one of myriad strategies corporations are following. There are also cases - typically involving projects that failed due to Indigenous political (and legal) opposition - in which companies have sued state authorities for their failure to meaningfully consult impacted Indigenous communities and secure development from legal liabilities. For instance, Platinex, an Ontario mining company settled out of court after resistance from Kitchenuhmaykoosib Inninuwug First Nation prevented them from continuing exploration. Karen Howlett, "Mining Company Surrenders Claim to Native Land in \$5-Million Settlement, Opening Ontario's Far North”, The Globe Mail (15 December 2009), online: $<$ http://www.theglobeandmail.com/news/national/mining-company-surrenders-claim-to-native-land-in-5-millionsettlement-opening-ontarios-far-north/article1205845/>.

136 Slowey, supra note 6; O’Faircheallaigh, "Contractual Agreements", supra note 6; Montsion, supra note 6.

137 Montsion, supra note 6 at 115. 
In this section, I use a mining company's negotiations with a Gitxsan wilp to show how corporateIndigenous partnerships reconfigure but ultimately reproduce the legal structure of the settler colonial political economy. While corporations in Canada typically contract with Indian Act bands not traditional Indigenous authorities, the Delgamuukw litigation uniquely established the Gitxsan hereditary chiefs as the legitimate Indigenous authorities in Canadian law. In 2012 and 2013, Catherine Blackstock, Gitxsan hereditary chief Geel, signed a series of agreements with Atrum Coal, an Australian mining company, to enable her wilp to participate in and benefit from the company's exploration activities. ${ }^{138}$ Atrum was investigating the anthracite coal development potential of the Groundhog Project, a 220,000 square metre plot situated southeast of the Klappan River. The project was on the traditional territory Xsi Miin Anhl Gii under the stewardship of the matrilineal Gitxsan house group headed by Geel. For Atrum Coal, the negotiated agreement secured the support of the Indigenous titleholder, and thereby functions to immunize resource development to Indigenous land claims. In accordance with the emergent norms of corporate contracting to secure Indigenous support for development, the negotiations between Atrum Coal and Geel occurred without the direct involvement of the Canadian state, a departure from prior practice in which the provinces brokered corporate-Indigenous relations. ${ }^{139}$

For Wilp Geel, negotiated agreements served to document, in contractual form, the benefits they can anticipate from the development. Geel described a number of economic benefits that flowed from the initial 2012 Exploration Access and Relationship Agreement:

Last year we were able to put a number of our members to work and this year we hope to take on more responsibility in the camp operations. We received funding for our members to get training in drilling, first aid, geology and basic camp courses. We hope to continue to expand training to include camp management, expediting, cooking, archeology and environmental [monitoring]. ${ }^{140}$

Through signing the agreement and providing job and training guarantees, Atrum was able to reconcile development with Geel through job offers, nudging the exercise of a Gitxsan territorial jurisdiction towards an indigenized technique of securing employment contracts. Describing the agreement, Gino D'Anna, Executive Director of Atrum Coal, stated, "We have ... been able to secure unencumbered exploration access with our First Nations stakeholders." ${ }^{141}$ The agreement established the terms on

138 Jerome Turner, “Gitxsan Chief Negotiating with AUS. Coal Corp.”, Inter News (17 April 2013) B7; Atrum Coal, Annual Report 2013 (Subiaco: Atrum Coal, 2013), online: < https://issuu.com/blackpress/docs/i20130417070755816/39> [Atrum, 2013].

139 Critics have argued that this outsourcing of responsibility for state obligations to corporations does not challenge colonialism as much as it extends the neoliberal privatization of governance. Emilie Cameron \& Tyler Levitan, "Impact and benefit agreements and the neoliberalization of resource governance and indigenous-state relations in northern Canada" (2014) 93 Stud Polit Econ 29; Guillaume Peterson St-Laurent \& Philippe Le Billon, "Staking claims and shaking hands: Impact and benefit agreements as a technology of government in the mining sector" (2015) 2 Extr Ind Soc 590. While sympathetic to such arguments, I want here to focus on the forms of jurisdiction that structure these agreements.

140 Quoted in Turner, supra note 138 at B11.

141 BRR Media, Atrum Coal Build Substantial Coal Position in Canada (Subiaco: Atrum Coal, 2012) 0:58, online $<$ http://www.brrmedia.com/event/106304/mr-gino-danna-executive-director>. 
which Geel would support development on Xsi Miin Anhl Gii and thus provided Atrum Coal with greater security in their investments.

In 2013, Atrum and Geel followed the initial agreement with a 2013 Construction and Equipment Loan Agreement, supporting the wilp to establish itself as a functioning company providing camp services to support mineral exploration. Specifically, Atrum provided an interest-free $\$ 100,000$ loan "to enable Wilps Geel to secure hardware and construction equipment for the construction of the exploration camp at the Groundhog Project as well as provide general working capital."142 Following the establishment of the exploration camp, the loan was repaid in four installments, which Atrum deducted from invoices due to Geel Enterprises for camp services. ${ }^{143}$

The linkage of elements of traditional Indigenous and corporate authority, embodied in an agreement between a hereditary chief and a minerals exploration firm, highlighted a reorientation in the pattern of colonial governance in British Columbia. The agreements were both the product of and productive of new legal relationships in the traditional territories of the Gitxsan hereditary chiefs. The corporateIndigenous agreements established employment and education supports for wilp members and provided start-up capital to enable the incorporation of the wilp. Thus, corporate-Indigenous contracting provided avenues for the wilp and its membership to benefit from the development of Xsi Miin Anhl Gii.

Wilp members were now being trained to work in industry on their territories. Rather than displacing Indigenous connections to the land, industrial training and employment regimes worked to reconstuct prior bonds between people and place, establishing a form of industrial Indigeneity. This is a vital revision: where prior colonial policies sought to genocidally enfranchise Indigenous peoples into the imagined undifferentiated mass of Canadian citizenry, new educational programs charted forms of Indigenous empowerment that simultaneously embraced Indigenous territorial relationships and resource extractive development regimes. Rather than dispossessing people from the land, this new regime of recognition sought to reterritorialize people in place, reconstructing Indigenous bonds to their traditional territories in relation to the requirements of capitalist resource extractive development. ${ }^{144}$ Indigenous industrial labour thus resignified attachments to traditional lands while serving the requirements of capital. ${ }^{145}$ In this scheme for reconciliation, participation in industrial development becomes the means for Indigenous people qua workers serving industry to secure their well-being on their traditional territories. ${ }^{146}$

Similarly, Atrum's extension of subcontracting opportunities to Geel Enterprises offered an avenue for Indigenous empowerment through participation in industrial development. The expression of wilp

142 Atrum Coal, 2013, supra note 138 at 67.

143 Atrum Coal, Annual Report 2014 (Subiaco: Atrum Coal, 2014) at 92.

144 Julia Dehm has made a related argument, describing how the emergence of a marketized conservation economy in Indonesia has displaced traditional Indigenous systems of land tenure and reincorporated Indigenous people as cheap labourers within conservation projects. Julia Dehm, “'REDD Faces All Around': Implementing Reducing Emissions from Deforestation and Forest Degradation in Indonesia” (2012) 10 Local-Glob Identity Secur Community 98.

145 For an extended discussion of the politics of Indigenous industrial education, see Tyler McCreary, "Mining Aboriginal Success: The Politics of Difference in Continuing Education for Industry Needs" (2013) 57:3 Can Geogr 280.

146 For a related discussion of how industrial training programs in Australia are governed by a desire to reduce Indigenous dependency on government transfer payments, see Rebecca Lawrence, "Governing Warlpiri Subjects: Indigenous Employment and Training Programs in the Central Australian Mining Industry” (2005) 43:1 Geogr Res 40. 
authority was channeled into the vehicle of a private business under Canadian law that could contract to provide expediting services for resource development companies. Catherine Blackstock is now both the hereditary chief of Wilp Geel and the president of Geel Enterprises. ${ }^{147}$ Thus, through opportunities provided by corporate-Indigenous agreements and incorporating her Indigeneity, Blackstock has been able to translate the unresolved territorial claims of her wilp with relation to the Canadian sovereign into a corporate vehicle that can partner in development.

Adopting legal forms recognizable to the colonizer demonstrates one way that Indigenous people find agency within a colonial system; however, the forms of recognition accorded by colonial regimes remain selective, channeling the expression of Indigeneity into the forms most reconcilable with the legalities of capitalist political economy. ${ }^{148}$ Corporate-Indigenous contracts distribute benefits to Indigenous peoples better than models of settler colonial development that completely discounted Indigenous territorial claims. But the calculus of costs versus benefits relies upon an assumed normative frame, a model for the ideal conduct of lawful relations. Thus, rather than asking whether corporateIndigenous contracts provide a good deal, it is necessary to ask what normative order governs these contracts. How does corporate-Indigenous contracting relate to the conduct of Gitxsan jurisdiction? Does corporate contracting modify how Gitxsan people conduct lawful relations? What are the legalities through which contracts are enforced?

Corporate-Indigenous agreements recognize a role for Indigenous authorities as participants in development, but nonetheless reproduce the foundational organization of political economic relations under colonialism. Indigenous peoples are not recognized as possessing the inherent authority to refuse development on their traditional territories. ${ }^{149}$ Indigenous peoples can choose between adhering to development that effects the dispossession of traditional territories with some negotiated share of the benefits, or simply undergo dispossession absent any palliatives. Securing Indigenous futures through corporate-Indigenous contracts reproduces, albeit in modified form, the political economy of the colonial present. Moreover, these contracts do not meaningfully extend political autonomy to Indigenous peoples as they lack the power to initiate development or to decide against it, and are limited to raising issues through consultation processes and consenting through private agreements with development proponents.

The reproduction of colonial political economic frames displaces ways of organizing relations within Indigenous legal orders. As Wolfe argues, the ability to produce a new political economic order on Indigenous lands requires the dissolution or radical reorganization of pre-existent Indigenous societies. ${ }^{150}$ Thus, the emplacement of Indigenous authority within the political economic structure of corporate-Indigenous contracts serves to normalize a fundamentally colonial legal structure, enacting a mirage of Indigenous empowerment bonded to legal frameworks of corporate-led development that continue to displace Indigenous legal traditions. A double gesture of inclusive exclusion incorporates

\footnotetext{
147 “Geel Enterprises Inc.”, online: Geel Enterp Inc <http://geelenterprises.com/home.html>.

148 Coulthard, supra note 76 at 25-78.

149 On the right of refusal, see Audra Simpson, Mohawk Interruptus: Political Life Across the Borders of Settler States (Durham: Duke University Press, 2014) at 1-36.

150 Wolfe, "Settler Colonialism", supra note 96.
} 
Indigenous peoples into a legal apparatus founded on their disappearance. ${ }^{151}$ The adoption of colonial models of politics and economics recirculates colonial notions of land as a resource, displacing Indigenous ways of codifying relationships to the land. ${ }^{152}$ New corporate techniques of geologic exploration and valuation overwrite traditional Gitxsan practices of coming into relation with a storied landscape. The language of the contracts reproduces the frames of Canadian legislation and jurisprudence; Indigenous legal traditions are nearly absent from these documents.

In the case of the Geel and Atrum, establishing a contractual relationship worked to reconfigure the workings of Indigenous authority and the practices of Indigenous territorial governance. Geel Enterprises' company website provides recognition of the various nameholders within the wilp; ${ }^{153}$ however, there are inherent tensions with the intermixing of modes of corporate and Indigenous governance. Rather than coordinating Atrum activities in accordance with the principles of stewardship established in Gitxsan law, engagements with Atrum have restructured how Blackstock expresses her authority as the hereditary chief Geel. While traditionally Gitxsan governance occurred through a process of public witnessing and validation of formal agreements in the feast, the agreement forged by Geel and Atrum has remained confidential. Catherine Blackstock, who holds the hereditary title Geel, did not disclose or discus the agreement in the feast, as she did not believe this to be "the forum to bring up this business." "154 Thus, the calculated convergence between corporate and Gitxsan interests operates within a nascent contractual domain of knowledge and practice outside the purview of the central institution of traditional Gitxsan governance. The lack of transparency around corporate-Indigenous agreements raises concerns that agreements may unequally or unfairly distribute benefits among members of the community of rights-holders. ${ }^{155}$

Within the broader Gitxsan community, the evolution of practices of corporate-Indigenous contracting has both its proponents and opponents. Within the Gitxsan community, there is general acceptance of the authority of a hereditary chief and wilp to determine how to conduct themselves with regard to their territory. Hereditary chiefs that are proponents of contracting with corporations invoke their traditional authority to determine what happens on the lands of their huwilp. Similar agreements to those that Geel/Geel Enterprises made with extractive resource companies have been made by other huwilp. For instance, Skii Km Lax Ha signed an agreement with mining exploration firm Pretium Resources, creating subcontracting opportunities for Tsetsaut Ventures Ltd, a company formed by the hereditary chief and her husband. ${ }^{156}$

151 Mark Rifkin, "Indigenizing Agamben: Rethinking Sovereignty in Light of the 'Peculiar' Status of Native Peoples"

(2009) 73 Cult Crit 88; Scott Lauria Morgensen, "The Biopolitics of Settler Colonialism: Right Here, Right Now” (2011) 1:1 Settl Colon Stud 52.

152 Coulthard, supra note 76 at 51-78.

153 “Wilps Geel History”, online: Geel Enterprises Inc <http://geelenterprises.com/our-history.html>.

154 Turner, supra note 138 at B11.

155 Courtney Riley Fidler \& Michael Hitch, "Impact and Benefit Agreements: A Contentious Issue for Environmental and Aboriginal Justice" (2007) 35:2 Environments 45; Ken J Caine \& Naomi Krogman, "Powerful or Just Plain Power-Full? A Power Analysis of Impact and Benefit Agreements in Canada's North" (2010) 23:1 Organ Environ 76; O’Faircheallaigh, "Community Development", supra note 5.

156 Aboriginal Business and Investment Council, "Skii km Lax Ha First Nation and Pretium Resources", (n.d.), online: Sharing Success <http://www.bcabic.ca/content/skii-km-lax-ha-first-nation-and-pretium-resources $>$. It should be noted that the Wilp Skii Km Lax Ha, while participating in feasts with Gitxsan huwilp, identify as Tsetsaut people. 
However, conflicts have arisen over hereditary chiefs signing onto developments that impact multiple huwilp territories. ${ }^{157}$ As Val Napoleon documents, the displacement of traditional Gitxsan dispute reconciliation processes by the imposition of Canadian law has exacerbated conflicts. ${ }^{158}$ Corporate agreements with hereditary chiefs have been subject to community resistance, both through direct action and litigation in the Canadian courts. Dissident hereditary chiefs and band governments have sought, unsuccessfully, to litigate against the authority of a society established by the hereditary chiefs to represent the collective territorial interests of the Gitxsan people. ${ }^{159}$ Some hereditary chiefs have opposed agreements with extractive resource companies on the basis that the negotiation of these agreements has not been conducted in accordance with Gitxsan law. ${ }^{160}$ As Gitxsan people continue to articulate forms of legal difference irreconcilable with colonial regimes of resource extraction, they demonstrate the enduring legal plurality of Gitxsan territories. The emergence of corporate-Indigenous contracts reflects one effort to restrict or channel this plurality.

While the agreement between Geel and Atrum was transnational, this distinction reflected a reiteration rather than rebuttal of colonially-imposed legalities governing the political economy. Scholars have interpreted the entry of a transnational corporation into direct contracts with Indigenous peoples as a disruption of Canadian sovereign authority over Indigenous peoples. ${ }^{161}$ However, the

157 The most prominent of these disputes surrounded the decision of a Gitxsan hereditary chief to sign an agreement with Enbridge Northern Gateway (a limited partnership proposing the development of a tar sands pipeline). Although the chief was lead negotiator with the Gitxsan Treaty Society (a non-profit society representing the territorial interests of a majority of the Gitxsan hereditary chiefs), and initially signaled that he signed on behalf of the entire Gitxsan community, there remains substantial ambiguity regarding what authority he possessed in entering the agreement. The details of the agreement are cloaked in secrecy, but multiple factions in the community disavowed his right to represent them. See Dirk Meissner, "Lone B.C. chief backs Enbridge pipeline to bring in more jobs", The Globe Mail (15 January 2012), online: $<\mathrm{http}: / / \mathrm{www}$.theglobeandmail.com/news/national/lone-bc-chief-backs-enbridge-pipeline-to-bring-inmore-jobs/article1358930/>; Wendy Stueck, "Gitxsan insists Enbridge deal never had its support", The Globe Mail (7 June 2012), online: <http://www.theglobeandmail.com/news/british-columbia/gitxsan-insists-enbridge-deal-never-hadits-support/article4240937/>.

158 Val Napoleon, "Who Gets to Say What Happened? Reconciliation Issues for the Gitxsan" in Catherine Bell \& David Kahane, eds, Intercultural Dispute Resolution in Aboriginal Contexts (Vancouver: UBC Press, 2004) 176 at 188-189.

159 Spookw v Gitxsan Treaty Society, supra note 25. The Spookw case principally involved whether the Gitxsan Treaty Society could speak for the huwilp, and by extension the Gitxsan people, in negotiations and consultations with the Crown. The plaintiffs included six Gitxsan hereditary chiefs, four Gitxsan bands, and a Gitxsan non-profit society. They asked the court to effect the winding up of the Gitxsan Treaty Society because it was not acting in the interests of the Gitxsan people. The court dismissed the plaintiffs' claims because they lacked standing to challenge the activities of the Gitxsan Treaty Society. In the view of the court, the authority of the Gitxsan Treaty Society was constituted bidirectionally: via its recognition by state treaty negotiators, on the one hand, and via the participation the Gitxsan hereditary chiefs that formed the society's membership, on the other hand. The court recognized bands as statutory creations of the Indian Act, responsible for allocating monies and providing services to reserve communities but independent of the Gitxsan Treaty Society. Similarly, the Gitksan Local Services Society lacked standing. The six dissident hereditary chiefs had the opportunity to become members and participate in the Gitxsan Treaty Society; however, they refused membership and therefore also lacked standing to make claims against its performance under the Society Act. The court thus upheld the ability of the Gitxsan Treaty Society to negotiate agreements on behalf of the Gitxsan huwilp with respect to the claimed Gitxsan traditional territories.

160 See $A$ New Beginning (Hazelton: Ardea Films, 2011). online: <https://vimeo.com/33252943>

161 Slowey, supra note 6; Montsion, supra note 6. 
relationship between political sovereignty and transnational corporations needs to be understood in terms of the definitional relationship between politics and economics under capitalism. With the division of politics and economics, "a fundamental distinction came to be made between political possession of territory and economic ownership, so that even the enemy's property rights were protected." 162 Thus, the globalization of the political form of sovereignty constructed the conditions of possibility for the emergence of global private enterprises unhinged from local responsibilities to any particular state. As the relationship between corporate and sovereign authority transformed in the shift from imperial mercantilism to settler colonial capitalism, the relationship of hereditary chiefs to the Hudson's Bay Company should be understood as distinct from the relationship of Geel to Atrum. Rather than chartering corporations to enact on behalf of the state, settler colonialism corresponded with the emergence of regimes of global private enterprise. Atrum, thus, reflected an articulation of the globalized corporate power constituted on the basis of a transnational private economic domain.

Simultaneously, settler colonialism heralded the emergence of new forms of political authority vested in the colonial state. The agreement between Geel and Atrum, relied upon and reinforced the importance of the settler colonial state as a political regulator of economic activities. It was British Columbia mining law not Gitxsan legal traditions that first structured and instituted the possibility of mining exploration companies' entry into Gitxsan lands. Under British Columbia law, mining companies do not start by seeking permission to enter and use the land from the hereditary chief. Rather, access to sub-surface rights is facilitated by the legal framework of free-staking, established by the provincial Mineral Tenure Act. $^{163}$

The issuance of mining titles that permit exploration without consulting with the local Indigenous population exemplifies the disrespect of Indigenous people in the Canadian legal system. ${ }^{164}$ The provincial gold commissioner administers mineral rights in British Columbia through a free-entry system with an online mineral titles registry, enabling private actors to acquire and maintain mineral title - which provides rights to explore for, develop, and produce minerals. A mineral title also conveys a right to use, enter, and occupy the surface of the claim for the purposes of mineral exploration, development, or production. This legal framework encourages and promotes exploratory drilling work, which is constituted as a right of mineral titleholders. As Myrian Laforce, Ugo Lapointe, and Véronique Lebuis describe, "free mining includes not only the possibility of freely acquiring ownership rights of the mineral resources of the territory, but also provides guarantees concerning the right to engage in exploration to seek out these resources, and, in cases of discovery, right to extract and use them." 165 The legal framework of free-entry mineral staking thus relies upon and reproduces asymmetrical power relations, in which Indigenous legalities and interests in the land are rendered secondary to the logic of mineral development. ${ }^{166}$

162 Buck-Morss, supra note 113 at 15.

163 Mineral Tenure Act, RSBC 1996, c 292.

164 Dawn Hoogeveen, "Sub-surface Property, Free-entry Mineral Staking and Settler Colonialism in Canada" (2015) 47:1 Antipode 121.

165 Myriam Laforce, Ugo Lapointe \& Véronique Lebuis, "Mining Sector Regulation in Quebec and Canada: Is a Redefinition of Asymmetrical Relations Possible?” (2009) 84:1 Stud Polit Econ 47 at 55.

166 Rebecca Hall, “Diamond Mining in Canada's Northwest Territories: A Colonial Continuity” (2013) 45:2 Antipode 376; Hoogeveen, supra note 164. 
State environmental assessment processes further regulate the conduct of resource extraction, in terms of developing and exploiting a productive mine. In Canada, the environmental assessment process is a central means through which the government fulfills its sovereign duties to consult and accommodate Indigenous peoples. ${ }^{167}$ These processes create institutional spaces in which Indigenous peoples can express their concerns and press for regulatory conditions to be imposed on development. ${ }^{168}$ However, they have been regularly criticized as best serving "as a process for incremental project improvement, and at worst as being little more than a feeble attempt at project legitimization." 169

In sum, corporate-Indigenous agreements rely upon and reproduce the organization of knowledge into economic and political domains based not in Indigenous legal traditions but rather the lineage of settler colonial law. Settler colonial modes of governance have centrally relied upon structures of knowledge that define economy as both a form of reason orienting the practice of government and a social field distinct from politics. Within this overarching structure, Indigenous authorities have made strategic choices, leveraging the uncertainty associated with their land claims to acquire a seat at the negotiating table. Corporate-Indigenous agreements provide a means to ensure that development serves to provide at least some benefits for some Indigenous people. However, contrary to the claims of those that would celebrate the decolonial potential of these partnerships, Indigenous peoples have not radically unsettled the operations of colonial political economy but developed new means to subjugate themselves to it. Their authority may now be recognized, but their conduct is guided by conventions of corporate practice and state resource law rather than Indigenous legal traditions.

\section{CONCLUSION}

In this essay, I have sought to chart the shifting assemblage of state-corporate-Indigenous relations through mercantilism, settler colonialism, Indigenous resurgence, and corporate-Indigenous partnership. At different historical junctures, Indigenous authority has been supplemented by the conduct of imperial mercantile sovereignty and supplanted by the conduct of settler colonial sovereignty. Through this history, the conduct of sovereign rule relied upon processes of territorialization for its coordinates and corporate authorization for its engine. In recent decades, Indigenous mobilizations in Canadian courts have challenged the elision of Indigenous jurisdiction in settler colonial resource governance practice, and thereby problematized corporate forms of extractive resource development. To resolve investment uncertainty, corporations have increasingly sought to directly engage Indigenous peoples, offering to recognize and negotiate with Indigenous authorities, thereby resecuring the legal foundation for development. While some scholars have imagined corporate-Indigenous partnerships as an expression of Indigenous autonomy or self-determination, this perspective seems Pollyannaish.

167 Annie L Booth \& Norm W Skelton, "Industry and government perspectives on First Nations' participation in the British Columbia environmental assessment process" (2011) 31:3 Environ Impact Assess Rev 216; Kirk N Lambrecht, Aboriginal Consultation, Environmental Assessment, and Regulatory Review in Canada (Regina: University of Regina Press, 2013).

169 Ana Maria Esteves, Daniel Franks \& Frank Vanclay, "Social Impact Assessment: The State of the Art" (2012) 30:1 Impact Assess Proj Apprais 34 at 37. 
Positioned in relation to the historical transformations that underlie settler colonialism, the contemporary emergence of corporate-Indigenous agreements can be understood as a revision and reinvention of the colonial political economic order. The purported decoloniality of corporateIndigenous agreements must be tempered by the recognition that these agreements reflect colonial traditions of organizing political economic relations. Rather than emancipating the exercise of Indigenous jurisdiction, corporate-Indigenous contracts cleave off shards of Indigenous selfdetermination and bond them to corporate capital.

Corporate-Indigenous agreements do not reflect a meaningful recognition of Indigenous modes of conducting lawful relations. They may be negotiated without the participation of representatives of the state, but they still reside in the shadow of state power, as it is the Canadian court system that secures these agreements. Moreover, corporate programs of development are still governed by the Canadian state on the grounds of a settler colonial territorialization of the land as resource. Corporate-Indigenous agreements are thus best understood as a supplement to rather than displacement of settler colonial law. These agreements institute additional regulatory conditions to guide development activity and provide Indigenous people with opportunities to participate in corporate programs of economic development as workers and subcontractors; they do not disrupt the foundations of the settler colonial political economy or evidence an Indigenous right to refuse development on their traditional territories.

Examining corporate-Indigenous partnerships, it is difficult to discern where exactly Indigenous political sovereignty or autonomy resides, as development continues to be effectively governed by the political apparatuses of state and development itself is a non-negotiable end point. At best, corporateIndigenous agreements represent a pluralization of regulatory apparatuses, with Indigenous authorities supplementing state regulatory efforts to modify the capitalist political economy to better serve Indigenous interests. At worst, these agreements are an artifact of Indigenous authorities using the leverage of the legal irresolution (according to Canadian law) of their people's land claims to construct opportunities for themselves. In either case, these agreements make Indigenous life fit within capitalist regimes. ${ }^{170}$ If corporate-Indigenous agreements are an expression of Indigenous sovereignty, it appears clear that this model of sovereignty is one burdened with colonial legacies.

I am uncertain what it would mean for an emancipatory Indigenous movement to achieve sovereignty. Nor is it clear what it would mean for the land and the resources beneath the land. The conduct of sovereign jurisdiction seems to inherit from colonialism a framework that externalizes the economy as a distinct domain from the political. This delineation conflicts with Gitxsan traditional frameworks, which do not divide economic and political life. Governance authority within the Gitxsan legal order fundamentally relies upon the enactment of social responsibilities to care for the land and distribute the produce of the land to the broader community. In contrast, the liberal model of territorial sovereignty establishes legal norms for corporate economic activity. Within this model, it is the mobilizing power of capital that drives development. Political authorities can make selective interventions to orient economic activity to best serve the welfare of the people, but mobilizing regimes of development ultimately remains a private (corporate) responsibility. Thus, appropriating sovereignty

170 My prognosis of the prospects for Indigenous emancipation through corporate contracts is resonant with Wendy Brown's portrayal of the prospects for democracy within neoliberal regimes. Wendy Brown, Undoing the Demos: Neoliberalism 's Stealth Revolution (Cambridge: MIT Press, 2015) at 17-46. 
as the vehicle to advance self-determination still leaves Indigenous peoples dependent on harnessing themselves to the engine of corporate power to achieve well-being. Corporate-Indigenous agreements may ensure a fairer distribution of the economic benefits of extractive resource development for Indigenous communities; but they do not break from the lineage of settler colonialism or the preeminence of the settler state and its subjugation of Indigenous laws.

Decolonization must involve more than simply incorporating Indigenous authority qua contractors within the reigning political economy. Indigenous autonomy as a practice of emancipation requires Indigenous people determine their future independent of imposed political economic structures. When the Gitxsan hereditary chiefs sought to contest colonialism in the courts, their central claim was one of jurisdiction. The hereditary chiefs presented not simply a competing form of authority, but also a competing mode of conducting lawful relations. As Shiri Pasternak reminds us, recognizing Indigenous jurisdiction "challenges Canadian law's claim to being the only legal order and foregrounds the multiplicity of forms of governance across the country." 171 To decolonize law, it remains necessary to displace Canadian law and its foundational divisions, reconstituting our conceptualizations of lawful relations in congruence with the distinct ontologies that undergird the practice of Indigenous jurisdiction.

171 Pasternak, supra note 17 at 147. 